\section{A-33）広範囲熱俉患者の胸部 $\mathbf{X}$ 線像}

付瘦病院放射線科西川博・渡部英之 行武純一・椎葉 忍・唐沢正明 本多一志䣡・走雄・疋田史典 耦井盛一・奥山厚

救命救急センター 大塚敏文・柳 郁夫 黒川 顥·相沢 理 $\cdot 太$ 田 正

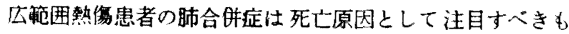
のである，熱汤のみの变化でなく，大量補液，感染などの因 子も含まれており，われわれはこの点に留意して，主にX線 学的立場加検副を加之た。対象は受鹪面積 $30 \%$ 以上の 35 例である. 異常影出現時期を受伤後 2 病日，3〜7病日，8病 日以降汇区切。て検討した。受鹪後 2 病日まではX線的に肺 水腫の所見が主で, 3〜7病日ではさらに，この傾向が增強し た.すなわち，血管影ボケ，眠門影ボケ・血管影增強・X線 透過性減弱などがその所見である。 8 病日以降では，研状影 air bronchogram など主に炎症を思わせる所見が多く認めら れた.このうち動㟲血培養により菌が同定した 8 例は，びま ん性球状影なと類似した傾向が認められた。 また，肺水腫と CVP 值および水バランスとの関倸について検討した. CVP 值が $10 \mathrm{~cm}$ 水柱を越之た 14 例では肺水腫様所見が多く認め られた。また，著明なバランスのブラスに数日晕れて，X線 写真上肺水腫が出現した

\section{B-1）不完全な咀哷に原因した下咽頭の大量出血 を生した症例}

\section{境島白十字病院耳殹喉科永野泰宏} 第二病院外科 天野純治・王 徳栄

咀啒譏能は食物の紫下および消化吸収の前段階として重要 なことである.今回煎餅を不用意に紫下した後に下咽頭媣部 の粘膜を損伤して多量の出血をきたし，かつ止血することが きわめて困難な症例を経験したので報告すると，同時に食物

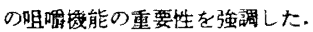

症例は 36 才の男性, 関節りュウマチと口内炎のため入院

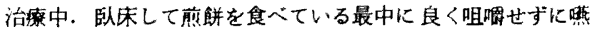
下した。䄪 5 分後に咽頭に熱感を訴え，吐血を生じた，患者 住咽頭壁汇噴水状の出秃感賞を訴えるが，咽頭の反射運動か; 強くて出血部位の確認は容易にできなかった。㡏血と補液で 経過をみたが止血しないため，気管切開をし全身麻醉下に䊑 查した結果，下咽頭深部に粘膜の膨隆を認め，てこから噴水 状に出血していた，止血操作はきわめて困難であったが，周 囲組織の電鈤灼で止血した。

㗪下運動には随意的な運動と不随意的な反射運動の 2 つが あり，食物が咽頭壁化達すると，その接触刺激により不随意 運動が生じる.㖓下圧は下咽頭の収維の際に $20 \mathrm{~cm}$ 水圧に相 当する圧力が食物に加えられる。したがって，口腔および四 頭粘膜に病変のある人や卧位で食餉をする場合は食物の勗嘅 を十分に行ない，與下もゆっくり行なら必要がある、下㸶頙 での出血を生じると此血操作がきわめて困難である.

\section{B-2）最近における突発性難聴の傾向}

$$
\begin{aligned}
& \text { 第二病院耳咽喉科 中村兼一 - 弓削庫太 } \\
& \text { 村上事司・中村 村上忠也 } \\
& \text { 永野泰宏 }
\end{aligned}
$$

炤和 43 年 1 月より 51 年 12 月までに当科を受㟝し，突 発性難聴の沴断基準（昭和 48 年度厚生省研究班）にしたが って突発性難㯖々影断された 88 症例について検行した。

男女比は $1: 1.2$, 患側比は右 : 左=1:1.2 汕側例はなか。 た。高発年令梳男性 20 才代, 30 才代，40 才代で，女性 30 〜50 才代であった。 10 才以下注 2 例，80 才以上は 1 例であ った.

12 力月別にみると，12月にとくに多く(なかでも6女性は 48 例中 13 例) 8 月, 11 月が少ない。発症より初颜までの 期間は 2 週間以内に約 $75 \%$ が受彭している. 聴力型では水 平型, 万型, 高音漸隇型の順比多く, 低音障害型, 山型, 谷型が少なかった。眩需は 29 例にみられ，そのほとんどが 一過性であった，一般検査の結果誘因となる基磁的疾患が考 えられる13 例がみられた。.ウイルス抗体洒を測定した結果， herpes simples は各年度に平均して高抗体価を示した。

心身の安静，星状神経節プロック，アミドトリソフート静 注, ATP 大量点滴静注, ビタミン $\mathrm{B}_{1}$ 複合, 循環改善䛥, 上 ランキライザーなどの治療を試み 39 例の改善をみた。

若年者で，発症〜治療開始までの期間が短かく，聴力損失 が少ない低音障害型，水平型の聴力像を示し，発症時に矓 を伴なわず，誘因となる基整的疾患を伴なわない例は予後が 很かった。最近では改善淁法向上し，昭和 51 年では 10 例 中 8 例の改善をみている.

\section{B-3）高度感音難聴者における electrical pro-} montory testing の評価について

\section{付属脑院耳咽㖫科神尾友和 - 馬場俊吉 橋本泰彦}

われわれ隹年 4 月に Los Angeles Ear Research Institute で開催された International Cochlear Implant Conference に参加し, 今後 2 年閒にわたる cochlear implant のプロジェ クト・チームの一貝としてわが国比ける Cochlear implant について换討を行なうことになった. Cochlear implant の適 沁にるものは，高度感音難聴者の中でも有毛細胞障害に 限られている. 有毛細胞障富とその他の障害による難聴とを 䟝する目的で, 1974 年に House らにより electrical promontory testing という検査法が提唱された. われわれは House らが考案された electrical promontory testing の刺激 装置を用いて 6 例の高度感音難聴者に electrical promontory testing を行った。検查は鼓膜の表面昨酔後鼓膜を通して金筃 極を捜入し，鼓空邮に固定し 低周波数 $30 \sim 120 \mathrm{~Hz}$ ，低電生 $0.3 \sim 1.2 \mathrm{~V}$ の電流で直接内耳を刺激し電流刺激に対する自 覚的反応の有無により有毛細胞障害か 否かを判定するもので ある. 6 症例 11 側の結果をまとめる.鼓膜穿孔のある 3 側に は反応は証められなかった.SMによる難聴と思われる 3 症例 
$-56-(434)$

6㑡についてはすべて良好なる反応が彗められた．さらに家 族性進行性難聴例と梅毒儿上ると思われる難聰例比ついても 反応が認的られた。なお，高度の耳鳴を訴えた 3 症例では， 刺激中に耳鳴の減少偭向が㥎められた。刺激中にメマイを訴 えた例，フレンッェル眼镜下に自発眼振が認められた例はみ られなかった。

以上から cochlear implant により sensory deaf の聴力改 着に可能性のあることが示唆された。

\section{B-4）下谷病院における水晶体手術の経験}

下谷病院眼和；三田首夫

水晶体手術は，谏結摘出器の普及により，摘出が，一 般化さ机つつある. 内摘出化打ける問题は，硝子体脱出の 防止であろう。この点関して，所々の対策が行われている が、決定的な方法はない，一方，派遣疗院における眼科手術 の現状は、術者一人で,すべての手術を行なわなばならな $\therefore$ 私仙過去 5 年間, 百数例の内摘出を経駼したので鞎告 する。

結論 : 術者一人で乎術を行っている晛状以合わせて，手術 の簡略化，硝子体眖出防止のために，言内摘出の手技，手順 を工夫し, 老人性白内障 94 例, 煻尿病性白内障 6 例, ステ ロイド白内障 3 例，研発白内障 2 例の内摘出を行い，その 結果，13 例に硝子体脱出を経倹した. 硝子体脱出防止に関し て, もちろん水晶体摘出時の術者の手技の巧拙か，重要なこ とは明らかであるが，助手に虹彩絢を使用させるだけで，摘 出は十分楽になる。このように硝子体脱出防止ということ一 つを取ってみても，術者一人で手術を行うことには，閔題が ある. 内眼部手術は，原則として，術者と助手とで手術を行 うことが，手技，手順の工夫と同様に，好結果をもたらすと 考えられる。

\section{B-5）人工水晶体移植術の経験について}

\section{第二病院眼科 内山幸昌・清水洋一 中山滋章 ·牛山節子}

片眼白内障手術後の視钱能障害を改善する目的で Binkhor。 st 型 Iris clip lens および Irido capsular lens, Medallion 型人工水晶体を水晶体摘出後眼内儿移镇し，それによって生 ずる合併症と視機能再建につき検討を加えた。

方法: 術前処置としてェコリシン点眼液を 1 日 5 回点眼， ダイフモックス 1 日 3 踶 2 日間内服. 術直前マンニダン 500 $\mathrm{ml}$ およびダイフモックス $500 \mathrm{mg}$ 点谪静注. 手術方法は球 結膜剥離後, 強角膜縁化 Dobree 法汇よる4 面切開を 190 度行

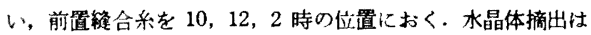

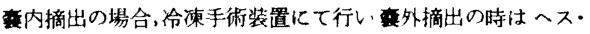
ダヒーール匙を用いて行う.その後 Binkhorst 型镂子にて人工 水晶体をつかみ眼内找入する. そして前置艇合米を締め追 加維合5 6 系打く. 術後処置は $1 \%$ ピロカルピン液1日3 回,毎日 8 週閒繶け，ダイフモックス 1 日 3 鍹 10 日間内服, デカドロン $1 \mathrm{mg}$ 球結膜下注射 1 日おき 1 週間続け以後りン デロン点眼湾 1 日 4 5 回点眼 8 週間続ける.

結論：1）人工水晶体によると思われる強い合併症は現在の

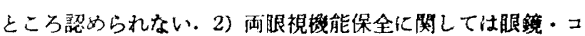
ンタクトレンズなどに比し良好である３）糖尿病患者の場 合，術後虹彩撚着はむしろ人工水晶体捅入した方が発生しに くい.

B-6) 2,6-drinethy 1-4-(3-nitropheny 1)-1,4dihydropyridine-3,5-dicarboxylic acid 3-[2-(N-benzy l- N-menihylamino $)]-$ ethyl ester-5-methyl ester hydrochloride による眼血管径の変化

\section{付属病院眼科 牛山節子}

2,6-drinethyl-4-(3-nitrophenyl) - 1,4-dihydropyridine3,5-dicarboxylic acid-3-[2-(N-benzyl- $\mathrm{N}$-menihylamino]-ethyl ester 5-methyl ester hydrochloride による眼血 管径の变化を，眼科に特有な血管の狭菅をその变化の特徽の 1つとしている. 租膜色慗変珄症の患者について検索した.

実験方法は，本绪 $5 \mathrm{mg} ， 3 \mathrm{ml}$ を觧注し，その前後の血管 径を, 样膜血管, 乳頭比, すなわち V/P で比較した. 眼底力 メラは Mamiya FR/200で，患者の眼を一定位置に固視させ ることが可能である.

症例数は 14 例, 14 眼, 明らかに拡張の認められたものは 8 例で $57.1 \%$, 同比率のむの3例で $20.97 \%$ であった。血 管径の抗張率は平均值が $4.76 \%$ て，有意差が認められた。

\section{B-7）菌状息肉症の 2 例}

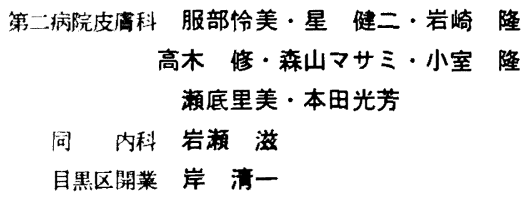

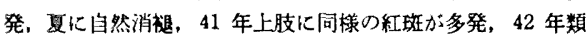
乾玅の診断でフルオシノロンフセトニド ODT、メトトレキセ 一ト内服治撩をうけた.

現症 : 殿部両上肢に大小不同の境界鲜明な鲜を付着する 紅斑が多発, 軽度癌䄳感あり。

組織所見：真皮上是に小円形細胞浸潤.

释過：45 年 5 月扁平浸潤期，50 年 5 月腫信期となり，全 身すい弱. 51 年 10 月 19 日死亡.

症例: 59 才, 女性, 初㖣; 昭和 50 年 3 月.

家族歷：特衻事項なし。

既往歴 : 45 才の時肺漫潤，54才の時肺結核

現病歷: 昭和 47 年 8 月, 右大腿部以紅斑, 49 年 8 月一時 皮疹消裉, 12 月背部以再発.

現症：全身に多発する不整形紅砇.

組織所見: 表皮内にポートリエの微小朖䜒真皮に組緎球り ンパ球様細胞漫潤。 
経過 : 43 年 4 月左乳癌のため左乳房全摘, 左腋简リンバ節

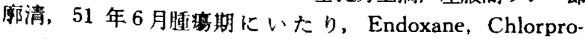
mazine，放射線、VEMP で治療したが，いずれも副作用の ため中止した.

本症は, Tcell Lymphoma であるが現在でも的確な治療法 がなく、紅玟期、扁平漫润期，腫韵期を経過し，死にいたる 他の Tcell Lymphoma とは異なる疾患単位と考える.

B-8）トリコフィチンの抗原性に関する研究一之 くに培鳌期間の長短が抗原性におよぼす影 慗—

\section{付属病院皮席科 野崎 昭・原田誠一}

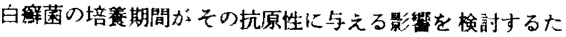
めに，培養期間 1 週から 1 年における各理のトリコフィチン （以下「ト」）を用いて沈降反応を行った結果を報告する。

実稌方法：抗原調製法; 星芷状菌野辺株を $4 \%$ サブラウ液 体培地比 $27^{\circ} \mathrm{C}$ 静置培蓄し，1，3，5，7，9，11 週，6 力月 1 年目の培意液より「ト」を調彆した。被験血清 : ウサギに星 艺状菌野辺侏を接理し，2週目上り每週 1 回心胀穿刺により 採血して、分離した血清を $56^{\circ} \mathrm{C} 30$ 分加熱し非慟性にしたも のを用いだ・沈降反応; 重層法により行い, 判定は室温で 30 分, 60 分, 120 分に行い, 抗原と血清の境界に生じた白色輪 状混渴の程度によった。

結果：1）培養 1 週目り「ト」にはまったく抗原性がない。 2）培篦期間が長くなるにつれて抗原性は上昇する.3)しかし， 6 力月，1年目の「ト」では抗原性が低下してくる.

以上より抗原性のもっとも高いのは，9，11 週の培意液よ り調製した「ト」であることが判明した。

\section{B-9） 爪刺（陥入爪）の手術}

\section{付属病院形成外科清見明子・百束比古 石井和博・小林明子・久保田昭男 文入正敏}

昭和 46 年以降，われわれは 20 例の ingrown nail を経 駼した。 うち 14 例が男性で，6例か女性，好発年令は 10 代 後半から 20 代で, ともに欧米の文献による頻度とほほ一致 していたまた，全例母趾であった５例江抜爪の既往があ り 1 例に爪白擗の合併があった. Ingrown nail に対する保 存的療法のうち，当科で勃果があるとして施行しているのは， 足趾の衛生, 靴および靴下への配虑、爪切り時の注意と感染 预である、このような保存的療法によって全治することは 少なく，われわれは根治的手術療法，すなわち Duvries 変 法を施行し，良好な結果を元た．今回は，その手術法をスラ イドで共管した。まず，術野を政重に消毒し，歌血帯をかけ

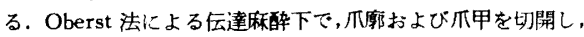
部分的拔爪を施し，爪遊を十分に開いて，爪母と爪床の一部 を趾骨に達するまで，鋭的に十分切除する，切除後の皮唐綪

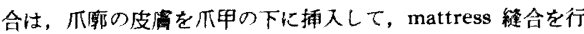
う.この京と，創仙，抗生物質含有軟高，トレックスガー ゼ,ガーゼの順にあて，压迫包帯を施す。拨系は，10 日目位
(435) $-57-$

で行いその間はへッド上での安静を保つ。おれわれは過去 6 年間に 13 例 18 趾にこの手術を施行し，1例の再発もみ ていない.

\section{B-10）大脳誘発脳波におよぼす硬膜外麻酔の影唔}

$$
\text { 付属病院麻酔科 大野孝生・久場 裹 }
$$

硬膜外晽酔において，注入された局所麻酔剒がどのような 機序で除痛効果をもたらすかということが問題とされてい る. 硬膜外麻醉は脊晽之は異なり, 分節麻酔が可能であるの

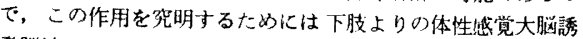
発脳波 (SEP) を䟕録し，その変化を検討することが重要だ と考えた。そのため，われわれは硬膜外晽醉のSEP に与え る影響を换副した・腹部手術を受计る患者に前投薬を投与せ ず硬膜外腔にカテーテルを㨂入した，下肢よりの SEP 法足 関節部の怪骨内顆上方 $1 \mathrm{~cm}$, 怪骨とアキレス腱との中心部を 選び, 脑波用針霓極を $1 \mathrm{~cm}$ の間隔をおいて刺し, 眆骨神経を 剌激することにより記録した。. $2 \%$ カルボカイン E 4〜 $5 \mathrm{~m} l$ 注入後，5，10，15，20，25，30 分に SEP を記録した，30 分 後に analgesia の高さをピンクリップ法で調べ，すべて高位 分節麻醉がえられたことを確認した. 結果として early component の振幅の诚少と, late component の遲延, 振幅の诚

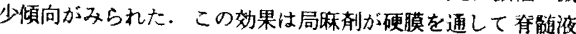

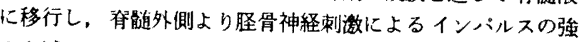
さを減したためと，硬膜外腔において前後根をブロックした ため, 末梢から恒常時化存する求心性インバルスの堿少をき たしたためだと考えられる。

\section{B-11) フローセン麻酔中に起きた上室性不整脈例}

\section{第一病院麻醉科 吉田 洋・横山和子}

われわれはフローセン麻酔中，興味ある不整脈を種々経駼 しているが，その中の上室性不整眽を報告する，症例は gastric cancer のため gastirectomy を施行した 64 才の女性で ある、術前, 血液検査, 心電四, 胸部 $X$ 線写真などに異常は みられなかった，算入は急速整入，維持は笑気酸素気泡体 (GOF) だ行った. 初めは何の異常もなく経過したが, 導入後 30 分で上室性不整脈が出現した。あらゅる原因を調べたが不 整眽が持綂したため, フローセンをきって経過をみると約 3 分後に不整脈は消失し正常状態にもどった。術後患者は何の 異常も訴えず術後心電四は正常であった，不整脈の心電図所 見は洞調律の基本的波形の他に異常波形を認めた．基本的波 形でも PQ 間隔が 0.20 秒と術前に比し, 延長がみられ ST-T が低下していた．異常波形では $\mathrm{PQ}$ 間隔の短縮と $\mathrm{R}$ 波波高の 低下，QRS 時間の延長を認めた。これらの不整脈はフローセ ン中止後 3 分で消失した. $\mathrm{PQ}$ 間隔短縮と $\mathrm{QRS}$ 時間の延長 は正常な房空伝導のパイバをを意味する，本症例では房空伝 誢に関する副层導路がありフローセンにより Mahaim 線䧽, James 束, Kent 束などが活性化されたと推測される。 また， フローセン使用中不整脈が長時間持続し，フローセン中止に てだだちに消失したことからこの不整脈がフローセンによる ことが強く示唆される。 


\section{B-12）陣痛と子宮頚管開大}

\section{第 2 産婦人科 青木基竞・菊池三郎 鈴村正勝}

分婏は子宫口の開大と内容の排出という2 過程からなって おり，その耐者比子宮收縮が大きく閵係していることは周知 の事实である．この子宮收縛を総合的に解粎し子宫口開大と の閣係を知るためにはいくつかのバラメータを組み合わせて 結論をだすことが必要である. 今回われわれは陣悀周期, 収 縮時間の持繶，收綟の強さ，収維開始よりビークまでの時間， 收箱の立ち上り角度の 5 つのバラメーターを設置し、これを コンピューターにより検討した。 キュライト社製マイクロト ランスジューサーを直接子宮腔内に㨉入し子宮内圧を測定し た. 初産㛿でオキシトシン使用例 6 例，非使用例 4 例を実駿 対象上し，その内压曲線の個々比つき各バラメーターを分析 した．相隣り合う収縮の規則性に関しては， $\left|x_{n}-x_{n-1}\right| / x_{n}+$ $x_{n-1}$ の式で計算した.

子宮口開大度別の分析の結果，収縮時間，收綰開始からピ 一クまでの所要時間では明碓な变化を認好かったが，陳痛 周期仕子容口開大とともに明らかに短縮し，収縮の高さおよ び收樎の立ち上り角度も堌強することを铝めた。また，オキ シトシン使用例の收樎は非使用例にくらべて明らかに早期よ りすべてのバラメーターにおいて規則的であることが証明さ れた.

\section{B -13）頚管成熱度スコアーと分娩予後}

\section{田村座榉人科 田村元良}

今回, われわれは日産婦学会の推蔡する方法による䅡管成 熟度スコ丁 (CMI と呼ふ）を試作し，一の結果と分婏経過と の関倸について，次の点で検討した。すなわち，(1)検査の買 同による誤差, 日時の経過による誤差の頻度, (2) CMI と自 然泍痛発来前の所要日数との関係. (3) 陣痛発来当日および最 終診察日の CMI 之分婏各期の所要時間亡の関係. (4)最終 CMI と鈴村によるバルトグラム上の分婏バターンと分婏予後

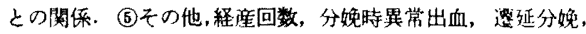
吸引分娘などとの関係について調べ次の結論をえた。

結諭：1〉この判定法により，内診上の祝差は䄪 $10 \%$ て あった２）自然陣痛発来が近うくと，CMI は高值を示す か，高値を示したからただちに陣痛が発来するとはいえなか った. 3） CMI は分娩予後を示すとはいい印れない．しか し，初産㜤においては，成熟群では分娩第I期は短樎する。

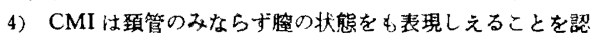
めた．5） CMIは分婏パターンとは無関係である.

B-14）産㛿人科悪性腫理患者のグラディエントゲ ル電気泳動法によるLDH アイソザイムの 分析の喭断的価値

第1産妇人科森卓司・大川了氿・大川公康 覀性腫盼患者の隐床検查における LDH アインザイムは高 值を示すといわれているが, 誩断的価値は十分でないので,
多数分画されるといわれるグラディエントゲルを使用し 娭討 した.

方法: 装置仕 Pharmacia の electrophresis apparatus GE-4 を使用し，支持体は Gradient Gell PAA 4/30 を用 い, 試料は採血後速や加遠沈し $-80^{\circ} \mathrm{C}$ 凍結し，3〜4 日以 内に泳動した. 一検体 $5 \mu l$ を使用した. $37^{\circ} \mathrm{C}$ 遮光染色を 3 時間 30 分行い、デンシトメトリーを行った. 正常健康婦人 11 人, 覀性腫泡患者手術前, 化学療法前 8 人, 手術後化学橑 法中の者11 人，再発した者 11 人，治原後経過良好の者 8 人に分けた.ザイモグラムは移動度の早い順に 9 分画に分け， LDH の単位に検垨した。

結果 : 手術前,化学獠法前の者汢，I，II，四 分画化增加し， $\mathrm{IV} \sim \mathrm{X}$ 分画に减少した. 手術後化学使法中の者は拳術前の者 に比べ I, II, III 分画が減少し, IV, V, VI 分画の增加を認 め大. 再発群汁手術後化学缭法中の者に比べ I, II, III 分画 の著明な增加， IV, V 分画の著明な隇少を認め, VI 分画では 新たに正常には認められない:ターンを認めた.これはデン シトメトリーは不能であった。治療後経過良好群は再発群比 比べ I, II 分画と隇少し，とくに III, VIIIIX 分画のいちし るしい減少を認めた。

結論：再発群において特異的パターンを認め, 今後卵巣癌 などの早期部断, 術後の予後の判定, 再発の早期発見に役立 つと思われる。

B-15） CAP を中心とした酳素学的胎盤機能検查 法へのアプローチ

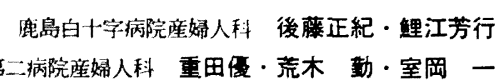

妊嫖血清中のシスチンフミノペプチダーゼ(CAP) 活性㑲 を, 正常妊娠, 子宮内発育遅延 (IUGR), 妊娠中毒症, 切迫 流・早産,胎内死亡, 胞状奇胎について測定し，正常例の $5 \%$ 葉却限界から正常限界を求め, 買常例と比較した。ささらに同 一例でロイシンフミノペプチダーゼ (LAP)，耐熱アルカリフ むスフォダーゼ (HSAP) を測定し，CAP との相互関係を比 較検討した。CAP 值は好娠 9 週頃上り徐々に上㫒し，妊妮 中期では非妊時の約 10 倍, 妊娠末期で 30〜40 倍となる. また，その值を常用対数に置換すると妊娠週数儿伴い直線的 に上年する. IUGR では，正常下限を境にして正常例と有意

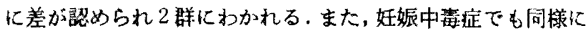
差が認められる. IUGR におけるこの傾向は，体質的要因に よるむのと、胎瞥㙨能低下に起因するものが CAP に現われ ていると思かれる，妪娠中毒症では，胎盤濑能低下例と正常 例とが CAP 值に反映しているのであるう。このように慢性 的胎整機能低下を推測される症例では，CAP 值の測定が有意 義であることが示唆された。また，CAP，LAP の相関では， 正常例での $\gamma=0.946$ に対し, IUGR で $\gamma=0.687$, 奼娠中 毒症 $r=0.827$ と正常例に比し相関が低い，また，CAP， HSAP の相関では正常例 $\gamma=0.814$ に対し, IUGR $\gamma=0.506$, 妊娠中毒症 $r=0.752$ 之相関が低い，これは胎篮機能不全でも 画一的な変化ではなく，症例比上り梯くの变化を示すことを

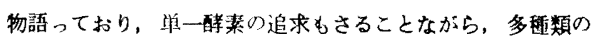
酳素の組み合わせにより，早期の診断が可能になる。 
B-16）母体血，胎児血およひ胎盤の這元型グルタ チオンの動瑟亡臨床像との関遧について

$$
\begin{aligned}
& \text { 第二病院産嫜人科 小宅正博·武井邦彦 } \\
& \text { 力武義之・進 純郎・肥田野邦子 } \\
& \text { 荒木 勤·室岡 - }
\end{aligned}
$$

生体にとって遗元型グルタチオン (GSH) は，磁妻的酸化 遗元に関与し水素伝達系の担体となる重要な物質である. 妊 娠に伴う母体血, 胎児血打よび胎盤についての GSH の存在 と活性は，いまだ検索されていない、今回，GSH が好娠とい う生理現象の中でいかなる量的変動を示すか，また妊娠およ び䏩児の病熊像と如何なる関連を有するかを検討した。

方法: 本院においてえられた姡婦 200 例, 胎児血 23 例, ヒト䏩篮 170 例の血中 GSH を Beutllr の方法, 胎笽 GSH を Klotzsch-Bergmeyer の睛慗分光光学的方法を用いて測 定した.

成績 : (1)奸婦近中 GSH 量は, 姡娠 16 週上り低下し初め 24 から 28 週まで最低値 $(15.8 \pm 5.72 \mathrm{mg} / \mathrm{dl})$ を示し，以後 きわめて繯徐に回復した. 流産例ではより低值を示した。坚 体重との相関は認められないが, 仮死例では明らかに減少し ていた. (2)上卜胎笽の好娠初期・中期・後期の GSH 活性は, それぞれ $14.51 \pm 7.9,9.16 \pm 5.10,17.7 \pm 8.49 \mathrm{mg} \%$ で後期 でもっとも高值を示した. 異常妊娠例では, 正常例に比べて 一般低低値を示した。

独創点：正常好娠䧴持に GSH が，強く閣与していること を初めて示唆した点にある。

\section{B-17）胎児の補体系について}

\section{三菱大會山病院産婦人科 大橋敏克 第 1 産婦人科 大川了氿・大川公康}

Fireman-Taylor は 1969 年胎児の䋠体系, とくに classical pathway を主体に追求したが，われわれはより原始的生体防 整系である alternative pathway を主体に梌索し，補体系 が, 胎児完成期の生体防整系で, どの程度の機能性を有するか を検討した. Classical pathway については $\mathrm{CM}_{30}$ ならびに C、について検索し, alternative pathway については Al$\mathrm{CH}_{50}$ ならびに $\mathrm{C}_{8} \mathrm{PA}$ を娭卖し, 併わせて $\mathrm{C}_{3}\left(\beta_{1} \mathrm{C} / 1 \mathrm{~A} \cdot \mathrm{Gl}\right)$ の免疫化学的蛋白量を測定した， $\mathrm{C}_{4} 、 \mathrm{C}_{3} 、 \mathrm{C}_{8}$ PAについては ドイッ・ヘキスト社製抗血清および標潐血清を使用し，一次 元免疫摭散法 (mancini 法) により測定した. $\mathrm{CH}_{\mathbf{5}}$ は mayer の変法を用い, alternative pathway の攏能的測定法として はウサギ赤血球の溶血法を用いた. 胎児 39 から 42 週の䐗帯 血の $\mathrm{CH}_{30}$ は $22.0 \mathrm{unit} / \mathrm{ml}, \mathrm{C}_{\text {、 }} 12.9 \mathrm{mg} / \mathrm{dl}$ で, $\mathrm{Al}-\mathrm{CH}_{30}$ は $8.6, C_{8}$ は $37.7 \mathrm{mg} / \mathrm{dl}, \mathrm{C}_{3} \mathrm{PA}$ は $9.1 \mathrm{mg} / \mathrm{dl}$ で, $\mathrm{C}_{3} \mathrm{PA}$ について出生第 12 日までをみると成人の $\mathrm{C}_{8} \mathrm{PA}$ レベルへと 次第に增加する傾向方認妨られる. 目児同一個体についてて はないが，胎児一成人の比费でみると $\mathrm{CH}_{50}, \mathrm{C}_{4}, \mathrm{C}_{5}, \mathrm{C}_{3} \mathrm{PA}$, $\mathrm{Al}-\mathrm{CH}_{30}$ はとれぞれ 0.52,0.39, 0.79, 0.49,0.47 ゙, 胎児 完成期では, classical, および alternative pathway の活性準 備状態レベルは，ともに成人のほほ $1 / 2$ を示し，補体系が主

要な役制を担なっていると考えられた。

B-18）小児真性尿崩症治療の変僈について一少女
の治療経過を中心に一 第二病院小咐和 加瀬 章・田村しのふ 小泉信彦・水野恭一・岡崎 修 笹本隆夫・宮田重人・太田秀穗

症例は昭和 41 年生九の女児, 6 才にて口渴多飲, 多尿を 主訴として発症, 尿量は $4,000 \sim 5,000 \mathrm{~m} l /$ day 尿比重は 1.002 と著明な低此重を示し、水分制限試験，カーター，ロビンス

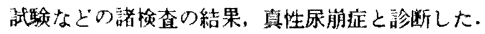

Pitressin tannate in oil で治族開始し 約 4 年問肪注を続 けていたか，奻果不安定であったため，昭和 50 年 7 月より clofibrate $750 \mathrm{mg} /$ day 経口投与したところ尿 量 $1.000 \mathrm{ml}$ day 内外，尿比重 1,010 前後と改善された．䄪 50 日間単独 投与し，その後は thiazide 刹との二者併用により1年 6 力 月程コントロールしていたが, 約半年程前より効果が潮隇し はじめ、夜間頻尿となったため、Vasopressinの合成誘道体 である DDAVP(1-deamino-8-d-arginine-Vasopressin) を チューブを用いて経算的に朝夕 2 回, 12 時閐每に $0.025 \mathrm{ml}$ ずつ投与した. DDAVP 投与後 1 時間以队で溶果発現し，尿 渗透压が正常化し，尿量も減少した．持続時間も10 時間続 きまた血圧上昇作用，粘膜刺激などの副作用もまったく 認められなかった。

投与後現在まで半年間連続投与しているが,一日尿量 1,000 $\sim 2,000 \mathrm{ml}$, 尿比重 $1,010 \sim 1,020$ とコントロールでき，血 清化学的にも何ら巽常なく良好化経過している.

以上, Pitressin tannate in oil, clofibrate, DDAVP と 一少女における治療变遷の経験を報告した.

B-19）新生児急性腹部症の 2 症例

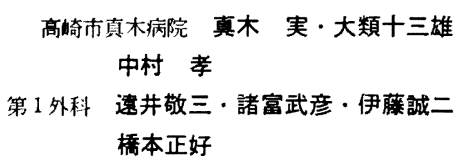

われわれ最近続けて新生児の急性腹部症の 2 症例を経驗 し、これを適切なる外科手術と術後処置により胈命しえたの で報告する。

症例 1 : 生後 3 日目の男児 $1,960 \mathrm{gm}$ の未熟児の罢穿孔, 新生児, 釈幼児ではきわめてまれな疾患であるが，穿孔，出 血を起した場合は重篤な状態になる，新生児期に消化性溃源 の穿孔した症例については従来手術成功例はきわめて少な く, 1950 年の Leger の手術成功例が最初であるといわれて いる，主症状は突然腹部異常膨满をきたし，産科より小児 科，当院と転院してきた症例である，消化性潰㾤穿孔は生後 1 週間以内起るすのが多く，とくに未熟児に多いという. なお，穿孔例中には先天性に罱筋層が欠如するものがあり， これは貲門部化多いとされているが，本症例は胃体中部後壁 に起ったもので，手術は穿孔部の綎合閉鎖，大網の維着によ って終った。 
$-60-(438)$

症例 2 : 生後 5 日目男子新生 児回腸の先天性粘膜下腫㾰を 原因とする回盲部イレウスで, 生後 3 日目より症状発現, 2 日間経過を観察，最終X線注腸診断でイレウスと部断，回盲 部切除術を施行し救命しえた例である。

以上，新生児救急手術の要点は，的確な診断，血管の確 保, per $\mathrm{kg}$ 何 $\mathrm{ml}$ という斻液, 㡏血量の部算, 体温の保持, 碄醉，出血防止にあり，可及的速やかにモスキト一鉗子など の小児外科用小型器械を使用して手術を施行し，消後の適切 なる術媵管理により救命しえるが，それと同㭙に痤科，小児 科, 外科の㗨密なるチームワークが肝要であると思われる。

B-20）新生児高ビリルビン血症における赤血球内 2,3-DPG 专の変娌について

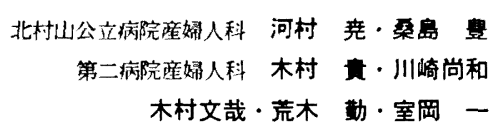

主として胎児赤血球の崩壤および旰の未熟性にもとづくビ リルビン生成過剩のため新生児高ビリルビン血症は生ずる. 本症の病態像および予後阔閣して赤血球内解棺系代謝の特異 性を検討する必要がある.そこで赤血球内化多量化存在する DPG が黄疸の進展にいかなる関連性を示すか検討した。

方法：正常新生児 35 例, 新生児高ビリルビン血症 40 例 について血清ビリルビン, DPG 量および赤血球膜の脆弱性 を求めた. DPG 量は Rose and Liebowitzの锖素学的方法, 赤血球膜の脆弱性は Parpart 法により測定した.

成績：1）本症に扎いてビリルビン量の上昇にともない DPG 量は增加し, $6.25 \pm 0.15 \mu$ moles $/ \mathrm{ml}$ RBC と有意な差 を示したしかし，交換輸血を必要とする症例では $4.81 \pm$ $0.41 \mu \mathrm{moles} / \mathrm{m} l \mathrm{RBC}$ と低值で有意な差を示した．2）溶血曲 線は本症においてビリルビン量の上昇に伴い，右方に位置し 赤血球膜の脆弱性は元進した．3）DPG 量か６.00 $\mu$ moles $/ \mathrm{m} l$ $\mathrm{RBC}$ 以上の症例儿光線療法後の rebound が生じやすい $(P=$ 0.0013).

結論：赤血球内 DPG 量がビリルビン笡および赤血球膜の 脆弱性の変化に伴い变動することから本症の病態像および光 線療法後の rebound を予測するための一つの指標となる。

B-21）当科における小児急性リンパ芽球性白血病 （ALL）の治療成績について

\section{付属病院小焻科宮本幹夫・峰田喬臣 若林恒郎・手代木正}

小归 ALLの治療は近年明らか炕進步し，その生存期問は 着実に延長している.しかし，治療が強力になるほど骨髄抑 制も強くなり，それらの対策のために入院を長びかせる傾向 が強くなり，生存期間注延長しても生存の質は低下してくる 可能性がある.こ机関して，四式による評洒はわずかに Burge らの報告にみられるのみである.われわれは過去 10 年間比 51 例の白血病を経験し, このうち ALL は 34 例であ ったが，1966〜1972 年までは Prednisolone と6 MP を主 とした併用瘵法を 18 例に行い (非 COAP 群), 1973〜1976
年までは主として,本邦では追試報告のいまだない,Spilrs ら の Medical Research Council Leukemia Unit 方式を 18 例に行った (COAP 群)。これらのうち初診封未治療で全経 過を追跡した例につき检討した. COAP 群は非 COAP 群 より有意に生存期間が延長していた。また，COAP 群には

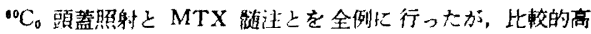
頻度に檤膜白血病の発生を認めた。COAP 療法の蒬解導入療 法では副作用は少ないが, 維持療法では骨跹抑制や感染症な どの副作用を多く認めた．生存の質比ついては，入院回数と 症状によって6段階評価し，また入院総日数と生存期間との 比を图式化し倸価したところ，COAP 群では入院回数がやや 多く, 非 COAP 群では種々の入院率を示し, 相対的生存の 質ではむしろ非 COAP 群の方が良い例もあることがわかっ た. 今後は COAP 療法の宽解渞入療法を活し, 維持療法を 改良しつつ, 生存の質と生存期間の両方の向上を計ろうと考 えている.

B-22）中枢神経白血病の予防療法を行った小児の ALL およひ AUL の検討

$$
\begin{aligned}
& \text { 第一病院小児科 小林正䆓・宮田昭三 } \\
& \text { 仁保幸次・守田利貞・宗像恵美子 } \\
& \text { 平田ひろ子・中林清美・植田 穆 }
\end{aligned}
$$

演者らは 1969 年以降 ALL および AUL に対し VCR， Pred により $90 \%$ 以上の完全宽解率をえており，寬解後は， 維持療法比文，2〜3 力月こととに強化療法を行っている.さ らに 1973 年以降は CNS Leukemia の䂆方潦法として M TX, Hydrocortisone, Arac の3者を強化療法ごとに噵注 し、 2,400 Rads の頭䈏照射を加えた.

今回は完全賽解後, この CNS Leukemia の予防を行った 18 例の成續を示し, 子防療法による合併症および初診時の臨 床症状，検査所見より治療に対する反応，予後の risk につ いて若干の検討を行い報告した。

18 例 (17 例俚初㟝より 1 年以上経過している) 中 CNSL を合併したものは1例で骨链の再発は1例もなく，初回宽解 を維持している最長例は 5 年に達し治瘵を中止した. Life table method による 5 年生存率は $81 \% ， 5$ 年初回宽解維持 率は 70\%である。しかし，予防療法による合併症として軽度 の呕吐，頭痛を除くと1のみ irreversible な encephalopathy を合併した。.また, 18 例中 3 例は筧解中感染症にて死亡 したが，CNSLの佊よりむしろ強化療法によるものと思わ れ、いずれも白血球减少のいちしるしい状態であったので免 疫不全によると思われる opportunistic infection に対する supportive therapy の重要性が考察された.この成繒を非子 防群 16 例と比較すると明らかにすぐれている.

B-23）腫痓免疫療法としての SSM（丸山ワクチ ン）と担癌患者への効果一第 1 報, 担癌患 者のリンパ球への影電—

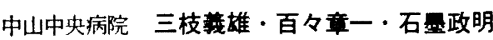

$$
\begin{aligned}
& \text { 柴田英司・阿波根昌信 } \\
& \text { 柴田千柣尚子 }
\end{aligned}
$$


SSM を使用したとき担癌患者リンパ球にどのような影锽 を与えるかを，1）E ロゼット・EAC ロゼット形成事，2)

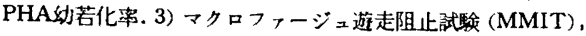
4）免疫グロブリン分画，の 4 項目を調べた.

結果：1) 免废グロブリン（IgG, IGA，IgM）については 投与群と非投与群の間比差を認めない。

2）Eロゼット形成率では投与群にやや低傎のものが多い が有意の差とはいえない。

3） PHA 幼若化率は投与群には正常箅囲を保つものがみ られ， T細胞実数には大差がないので投与群には $\mathrm{T}$ 細胞機能 穴進があるように思われる。しかし，症例が十分でないので さらに追求する必要がある。

4） SSM 使用後 2 3 カ月での PHA 幼若化率および MMIT には著変はなかった.

結論：SSM 使用により T細胞譏能が元進される印象があ るが，さらに例数を増して追求する必要がある. SSM 使用の 方法についても癌の軼類，時期，年令などを考虑して，有効 に作用させるための因子を見出すように努める必要がある.

\section{B-24）リンパ增殖性疾患に関する研究}

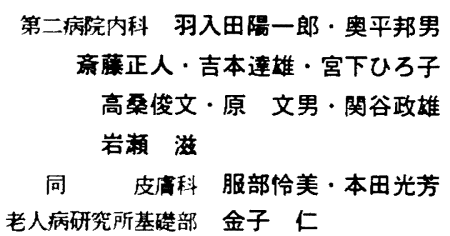

昭和 47 年 4 月〜 52 年 3 月までの 5 年間に, リンバ増殖性

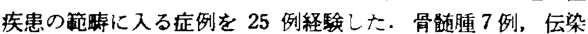
性巣核症 4 例, 胸腺原発㳂腫 3 例, 菌状息肉症 2 例, その他であり、このうち診断が困難な、あるい恃興味が持た れた 6 症例につき述へ， その腫理細胞の形態学的，免度学的 㛟討 (リンバ球 subpopulation, および免疫グロブリン測定) を行い，臨床経過，剖検所見と合わせ考察し，疾患の本態を 解明した。

症例 1 : 胸腺腫あり,末梢血に幼若リンパ球の出現をみ た. いわゆる sternberg sarcoma の白血化初期例である。 症例 2 : 男性, 末梢血儿異型幼者リン八球が $74 \%$ をしめ, こ の白血病細胞は，E-RFC を形成しており，高月らのいう， adult T-cell leukemia である. 症例 3 : 多彩な臨床症状を 示し, 急速に好中球, 好酸球の增多および血清 Ig の增加を 示し，白血病化して，短期間で死亡した細網症である.症例 4 ：血清および尿中に IgG Fc fragment $の \mathrm{M}$ 成分が出現 し, そのリンハ節像は Immunoblastic lymphadenopathy で あった，症例 5 ：骨领中心，小リン八球が $87 \%$ をしめ, 血清 $K, \mathrm{IgG} \mathrm{M}$ 成分を認め, 剖検にて肥厚した脂肪組織に， 丁 ミロイド沈着を認めた骨邻性リンバ性白血病症例である。症 例 6 : 菌状息肉症の患者で, 腫熘細胞が $\mathrm{T}$-cell origin であ ることが証明された。

\section{B-25）最近経験した転移性脳腫瘦の検討}

$$
\begin{aligned}
& \text { 付属病院脑神経外科 田崎寿人.伊藤保博 } \\
& \text { 松浦 浩·村山敦一・志村俊郎 }
\end{aligned}
$$

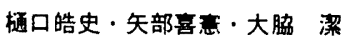

$$
\begin{aligned}
& \text { 中沢省三 }
\end{aligned}
$$

転移性腫演は全頭藍腫境の10２0\%をしめ，治療成續は生 命予後の点できわめて悲観的で脑㱏状出現時には末期症状と して手術の適応にならないことも多い。しかし，CT スキャ ンなど診断技術の進歩は脑神経外科で报う症例を增加させて いる.とくに CT スキャンは頭蓋内占拋性病変の影断にき わめて有用で, 当科です, CT スキャン導入後経験した症例 の一つでは数度にわたる再発に対し早期確定診断を可能に し, 手術, 化学療法, 放射線㙩法を反復し, 良好な成績を治 めている.この症例を中心に，最近当科で経験した転移性脳

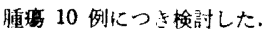

男 $8:$ 女 2 , 年令は $30 \sim 60$ 才代, 脑症状出現より猃断確定 は 3 6 力月, 手術可能例 8, 初発症状注䑈圧穴進症状か主, 発育仙単発 $60 \%$, 多発が $40 \%$, 天幕上が大部分をしめた。 原発巣は肺が $50 \%$, 病理組維は adenocarcinoma $50 \%$, squamous cell carcinoma $37 \%$, 調査時, 生存 $10 \%$, 死亡 $90 \%$ であった.

現在，われわれの手術適応は治療方針と直結するか，積極 的に脳圧六進汇対処し，化学療法, 放射線療法の併用に上 り，極力，延命をはかることを治療方針としている。

\section{B-26）脳の出血性梗塞の臨床について一臨床例の 検討を含めて一

$$
\text { 付属病院神経内科 古藤英明・吉田亮一 }
$$$$
\text { 二宮禽䆓 · 小沢英輔 - 伊東 亨 }
$$

脳の出血性梗塞なる概念仕臨床的化仕必ずしも新しいもの ではない、脳動脈の閉塞すなわち貟血性梗塞では, (1) 閉塞 性機転が急速に発生すること, (2)一度阻血した血管の再開 通時仙出血性梗塞が惹起されるすのと考える.このような病 変は, そのほか頭部外稘や脳腫㿋に伴う脑へルニヤや, 破裂 脑定動脈瘁の血管率縮を経過した脑にも認められる. 従来か かる脑梗塞の出血性梗塞への進展は臨床的にも症状経過の変 化から推測可能ではあった。すなわち、脳梗塞症例の意識レ ヘルの增悪, 項部強直の出現, けいれん, 呕吐, 瞳孔・眼球 運動異常、両側ベビンスキー反射の出現などがあり，髄液所 見での血性化などが，出血梗塞への進展の重要なポイントと 考えられる. また，私どすがすでに発表したごとく血管写上 梗塞血管の再開通時の像の特徽的所見として前および中大脳 動脈の (a) narrowing, (b) mass effect, (c) capillary brush, (d) residual stenosis のあることを示し, さらに近時 いちじるしい進歩をみる CT-scan を利用して梗塞柴の出血 病変を経時的にとらえることができた. 今回当科で経験した 2 症例は, 臨床および検查所見上定型的な脳梗塞が発症後 10 日前後任, 臨床症状の急激な変化および CT-scan 所見から 
$-62-(440)$

出㠸梗塞に移行したことが確涊されたものである.

当神経内科では脸卒中例の臨床観祭を群細に行い,かつ CT-scan の経時的実施を合せ行うことにより出血性梗塞例の 典型例を重ね，随時道切な治療を行って臨床成績の向上を計 りたい.

\section{B-27）意識湿蜀の評価法に関する䠦床的研究} (第 1 報)

\begin{tabular}{|c|c|}
\hline 東京労災病院脑外科 & 村岡 墚·金沢致吉 \\
\hline & 杉浦和朗 \\
\hline 救命救急センター & 西邑信男 \\
\hline
\end{tabular}

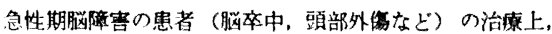
意部塆害の程度の把握はもっとも重要な指標の一つである。 その分類法（例えは，傾眠・昏迷・芷睡などの用語）にはか なりの混乱があるため，日常臨床上は，これらの用䃁を用い ず，音声や痛賞などの刺激比対する患者の反応様式を記載 し，意識レべル判定する傾向にある．演者らは「最大刺激 に対する最高反空」をみるE方式について発表してきたか， 太田らむ同梯の目的でいわゆる「3-3-9 度」方式なる試案を 提唱しているので，今回，両者の有用性について，科学的比 対比检討を行へた，万方法は，䐉神経外科的疾患で入院中の患 者約 300 名を対象とし，医師・看護職貝の協力のもとに，両 方式を上下にならべた郡録用紙を用いて，患者の意諳レべル の砰価判定を同時に記録し，約 3.700 対のデータをえた。 このデータを推計学的に処理し，合わせて両方式の論理過程 の連銷を分析した結果，E方式は，3-3-9度方式に比して，各 レベルの愦差籁囲が小さく、各レベル間も均等に差があり, 端理過程も簡明であるのに対し，3-3-9 度方式では，各レベル の誤差籁囲も大きく、各レべル間の差に坞等性がなく(その

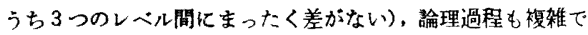
あることがわかった。この結果, 3-3-9 度方式は coma scale としては，成立しがたいものであることが判明し，E方式に る改良の余地がなとはいえないが，現状では，3-3-9 度方 式よりはるかに启頼性のあるスケールであると結論した。

\section{B-28）重侮頭部外䅉の検討}

\section{目白第二病院外科 奥出定明・矢岛民夫}

楠本春彦・岩㨽部臣・長谷川伝 付属病院脳神経外科山川和臣・村山亭一 田崎寿人・松浦 浩 · 矢鸠浩三

最近 3 力年にわたって入院收容された 2,100 名の頭部外甥 のうち，重賃例と晾断した 405 名について臨床的检討を加兑 た.重場頭部外賃と判断した診断基準は，頭部に関して4 週 以上の入院経過を必要としたもの，開頭手術を施行したもの， 意識障害を III-3方式により四の分類仁入り脑神経学的に左右

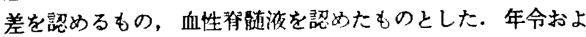
び性別についてみると，10才以下と 60 才以上がそれぞれ全 症例の 1 割を示し, 幼児・老令者に頭部外伤の受陽㙨転がよ り大きいことを示している．性別では男性に多く女性の3 倍
比至っている，原因をみると交通事故によるものが $82 \%$ でも っとも多く，転倒炕よるものは，小児に多い特徵をえた。少

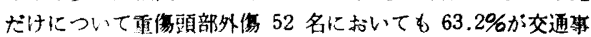
故が原因となっている.来院時施行される X線所見で住骨折 の有無は入院期間の長短とは密接な関係はない、意識障客の 程度の高度程は頭部外鹪に 起因する死亡す多く, 軽度意諳障 客で開喕に至った 15 例は宿没骨折であった。脑神释学的諸検

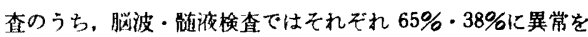

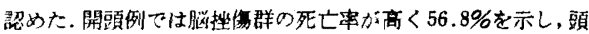
部外伤死亡の特異性を表わしている。重伤頭部外稘例の $27 \%$ が死亡に至っていることは嘼部外侮は致命的な外伤であり， 必要かつ十分な救急対応策が請じられねばならない。頭部外 伤が年令・受儗機枟・障害の脳汅おける局所性発生部位・意 流障客の発生時期により予後を决定する因子のようである.

B-29）過酸化脂兵と成人病に関する研究一第 2 報 加令による変化と心血管系疾患との関係一

$$
\begin{aligned}
& \text { 束急病院内科 各務満量子・岩城保仁 } \\
& \text { 川本道夫 · 高岡重博 · 加藤㓮志 } \\
& \text { 第 } 2 \text { 内科 新 城之介・赫竞郎 } \\
& \text { 永積傽・宮崎 正 }
\end{aligned}
$$

過酸化脂質牥老化現象および動脈硬化性病変の発生や進展 に関与するものとして注目されている.そこでわれわれは。 過酸化脂質の加令による变化および心血管系疾患との関係を 検䋈し，また新鲜脑卒中例についても測定したので報告する。

方法: 過酸化脂質の指標として, 血清 MDA 值を内藤变法 により測定した.

結果：健常者 100 例の MDA 值は加令により增加傾向を示 し，若年層，中年層，老年層の平均傎 $(\mathrm{M} \pm \mathrm{SE})$ はそれぞれ $9.03 \pm 0.20 \mathrm{nmol} / \mathrm{ml}, 9.25 \pm 0.18,9.88 \pm 0.24$ であって，老 年層は若年層に比し有意の增加を示した $(\mathrm{P}<0.01) . \mathrm{MDA}$ 值と血清脂質值との比較は，MDA と総コレステロール，燐 脂算, トリグリセライドとの間化恃相関は認めなかったが, $\beta$ リホ⿺蛋白との間には相関を認めた $(\mathrm{P}<0.05)$. MDA と心 血管系疾患との闒俰をみるため，WHO の高血圧重症度分類 により高血圧患者 148 例を分けると，MDA 值恃高血圧によ る眼器障害を伴うものは血生正常者化比し有意の增加 $(\mathrm{P}<$ 0.001) を示し， 60 才以上ではその傾向が著明であった。新 鲜脑卒中例（脑出血 8 例, 脑梗塞 26 例) について MDA 值 を経時的比锶察すると，発症後 2 週間ぐらいまではほとえど の症例で, 同年代の健常者および陳旧例に比し高値を示し， その後は潮城した。しかし，臨床経過不良例はさらに上异ま たは高值を持続した.脳梗塞例は脑出血例より高値を示し た.

B-30）老年者における持続的経静脈榶負荷試験 (IVGTT) の血糖およひインスリン反応 について 老人病研究所臨床部野崎琢史・㯃原部 大楠挀郎・嫊鳥昌平・盤若博司 
IVGTTの成績より老年者の酎結能異常が老化にもとつく 生理的なむのか，動脈硬化，智层病などによる病的なむ，のか を区別することが可能かどうか試みた。一方，50g OGTTに よる CPR の変動についで述べた。

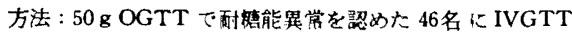
を行い，血楬とインスリンを測定した，对象者を若壮老年群 および OGTT の成縤儿より，正常・境界・榙尿病域に分類 して検討した. インスリン反応は面續比 $S_{I R I} / S_{B S} 20$ 分值 を使用し，CPR 反志にも面續比を用いた。

成精および結語：(1)血䗆曲線で頂值の $1 / 2$ に復する時間 $(T$ 1/2) は若壮老年群の順化延長した. $S_{I R I} / S_{B S} 20$ は若壮年群 でのみ境界城が蜻尿病城に比し高値を示した. (2) 老年群の $S / S 20$ では，動脈硬化庭を有する例では高值を示し，病的

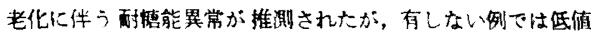
を示し蛅尿病性変化を有する例が多かった。 (3)若壮年群およ び動脈硬化症を伴わない老年群では T $1 / 2$ と $S / S 20$ はほほ

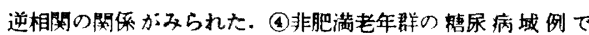
は，正常城例よりもCPR 反応は低檤の傾向を示した.

\section{B-31）Streptozotocin 裙尿 rat の体期位相に及 ぼす加令の影}

\section{营床病理青山昭徳・皆川 竞・渋谷昌彦 中撃 温・鈴木玩弥・宗像純司 岩䗁力・田中幸次 · E山元次郎 高山弘平}

付属病院中央模查室 細井元子・戸田惠美子

われわれは前回の報告において“ヒト”蝠尿病者の運動療 法が高龄者の代渐位相改善に重大な関傜があることについて

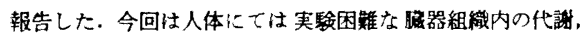
ことに榙筫，脂質，フミノ酸の代謝に及汪寸通動強度の影 整を追求した，ことに加数に伴った血中脂質増加に及ほす training 奻果を, streptozotocin 実駼等尿 rat (STZ, DM rat）を用い、眼器組織, 骨格筋肉の代謝位相を検討した。

方法：前回報告と同样である. 結果: STZ DM 群のうち, 軽度および高度 training 群, 非活動 DM 群抢よび健常対照 の各群間化体重に関しては有意差はなかった，遊離脂肪酸の

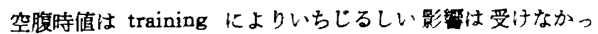
た. フミノ酸は一定の傾向が示唆された，血清中性脂肪江関

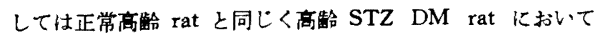
も軽度 training 群で低下し，高度 training 群ではかえって 増加を示した. 血模値についても同様な变動を認めた. 赤色 骨格胼肉中性脂肪は加黠化伴って堌加したが, 軽度 training により低下し，高度 training 群で增加を認めた。かかる運動 強度差による筋肉内のいちじるしい脂質変動の理由を明らか にするため骨格觔肉内 $2 \sim 3$ の醉素類活性を此較㭘討した。

結論：1）STZ DM rat において血桾値ならびに血清中性 脂肪注轻度 training 群にて低下し, 高度 training 群で堌加 を認めた．2）STZ DM rat において骨格觔肉中性脂肪は 軽度 training において低下し, 高度 training 群においては かえって軽度の上昇を示した.
B-32）微生物嫳剂ブロンカスマ・ベルナ（略称 B)，パスパート(略称 P) の皮内注射によ る侵性気管支资, 勘脈硬化症, 老人性白内 障，近視，その他の実験例（第 2 報）

福山市目永医院 畐永 天

昨年の総会の第 1 報告後， B , P の皮内注射で有効の疾病, および新しい事実が判明したので郝告する。新たに有勃の疾 病江次の通りである(病名の次の数字は効果判定実稌総人 具，B，P沬その使用区別，数字は人具を表す)。慢性気管支 炎 12 B 8 P 4, 凍鹪 18 B 16 P 2, 前立腺肥大症 5 B 5, 以

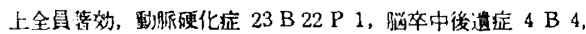

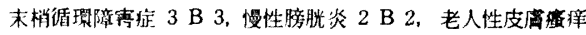
征 9 B 8 P 1, 耳鸣的 8 B 6 P 2, 九ニエール氏病 3 B 2 P 1, 近視 39 B $34 \mathrm{P} 5$ (児童では著奻例多し), 透視 34 B $32 \mathrm{P} 2$ 老視 $23 \mathrm{~B} 23$, 老人性白内障 $30 \mathrm{~B} 29 \mathrm{P} 1$, 動脈硬化症以下

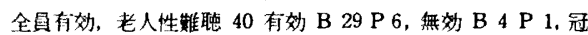
硬化症 10 (注射回数 25 回以上の者) 有奻 B 7 無勃 B 2

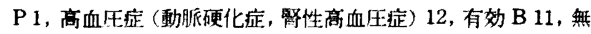
奻 B 1 であった。CB，BA，Rh. Aller.の主な原因の一つは

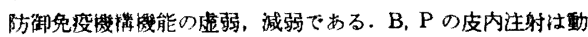

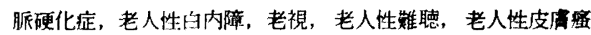
㾕症, 前出腺肥大症など有效であり，老化現象と防御免度 楼の機能低下とは密接な関連がある. B, P は老化防止, 改 善の一助として使用して価值市るものと判断する.防御免度

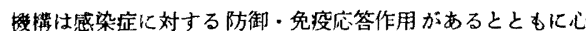

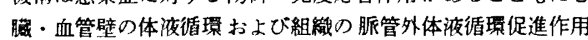
がある、B，P の上うな微生物製削の皮内注射は防御免疫機 構を刺激賦活して, その機能, 能力を改善, 增強し, 防御免

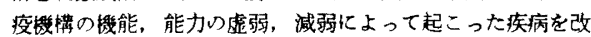
善し、京た老化現象を防止, 改善する。

\section{C-1）故長沢米蔵名誉教授剖検示説}

\section{老人病研究所基堡部 金子 仁}

臨床䃌: 昭和 51 年 9 月 5 日夕から夜間にかけ排ガスがな く、腹部膨满感，心䨐部痛が強くなった．9月6日朝より排 ガスなく、メンタ湿布をしたが症状は軽くならず夕方から呕 気が強くなり6回叹吐した。9 月 7 日朝, 日本医大第一病院 に入院. 入院時血圧 $104 \sim 70 \mathrm{mmHg}$, 発熱 $37.8^{\circ} \mathrm{C}$, 腹部俚膨 隆し、蠕動不䅰を認める、腹部単純掓影で小腸のガス像がい ちしるしく，大腸のガス像は認められない。機㳦的イレウス の診断で斉藤式イレウス管を捜入し， $2,400 \mathrm{ml}$ の胃内容を吸

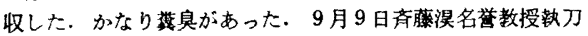
で腸痤造陪術を施行し，症状やや改善せるも全身衰弱いちし るしく，肺炎を惹起し 9 月 23 日永眠された. 行年 90 オ(以 上宫崎德藏内科医師記).

主要剖检診断：1）盲腸と小腸（トライッより $120 \mathrm{~cm}$ ）の 㾤着によるイレウス. 古い蛀炎が原因と考えられ, 線維性 虫垂周囲炎が認められる。疮着部空腸の口側は太く，肛門側 は細い，2）両侧著明な肺気腫および然下性肺炎（左 $460 \mathrm{~g}$, 
$-64-(442)$

右 $300 \mathrm{~g}$ ），3）前立腺肥大症，4）两督の老人性萎維（左 110 $\mathrm{g}$. 右 $120 \mathrm{~g}$ ，5）大動脈硬化症および腹部大動脈猪，6）著 明なオステオポローゼ、7)旰 $(670 \mathrm{~g})$ ，心 $(270 \mathrm{~g})$ の褐色萎

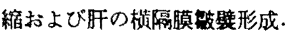

結铪：故長沢名誉教授は何年か前に䍜患された虫垂炎のた め空腸と盲腸が痹着していた，老年となり晹の動きが弱まっ た時に内容が停溜してイレウスを起こしたものと扯察され る. 直接死因は喫下性肺炎である。

\section{C-2）広背筋付籍娄の異常例一いわゆる Langer の腋窝弓について一}

\author{
第 2 解剖 吉川文雄・谷家章五 \\ 浅川光夫·北沢 命
}

広背筋付着部の異常所見として“過剩筋束”の出現が，し ばしば観察される．このものは石背脇の外側緑部に不定な腱 性ないしは解性索が加わるもので Rauber, 金子および森らの 解剖学成書によると 7 8\% (Krause, Double ら), あるい

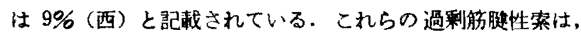
厈背筋の外例緑から分れ出て腋窝をこえ, 多くの場合仪は大 胸觔健付着部の後面化停止するか，また近位の他の部位比 停止することもあり、いわゆる Langerscher Achselbogen (1846 年 Langer により初めて報告される) と総括されてい

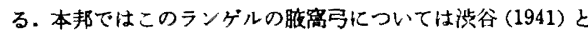
森（1950）か双胎々児の解剖学的研究の一環として精査報告 しており，この異常例は個体においては両側性にみられる場 合がもっとも多く，ついで左側にのみ出現するが右側のみの 出現は皆無であると結論している. 今回演者らの遭遇した例 は 81 才, 男性で, 広背筋以外の異常筋としては両側性に胸骨

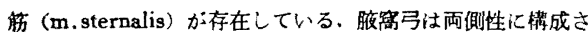

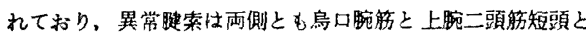
合して共通腱となり鳥口突起付着している，その大きさは 左側のものは幅徍 $1.60 \mathrm{~cm}$, 厚径 $0.08 \mathrm{~cm}$, 長湰 $4.07 \mathrm{~cm}$, 右側のものは幅往 $0.58 \mathrm{~cm}$, 厚往 $0.04 \mathrm{~cm}$, 長径 $3.37 \mathrm{~cm}$ で, 正常腱との間につくられる徤弓の最大幅は左側 $2.10 \mathrm{~cm}$, 右側 $1.84 \mathrm{~cm}$ であった. 左右の腱弓を通過する腋简の血管神 释束の異常は認められない。

\section{C-3）鋳型解剖法によるイヌ好娠子宮壁の血管に วいて}

$$
\begin{gathered}
\text { 第 } 2 \text { 解剖 吉川文雄 ·田沼久美子 ·小合和子 } \\
\text { 村上光伸 } \cdot \text { 系永煡一 }
\end{gathered}
$$

醍湖ら（1971）によるとイヌ子宫動脈主幹の 全経過は 4 型 に分けられ，主幹から子宮内膜に向かう主要分枝の数は右側 で 10〜14 本, 左側で 9 12 本と弲載され, また妊娠子宫で 胎盤形成似関与する動脈枝は一胎盤化つき $3 \sim 4$ 本とされて いる. 今回演者らはイ又妪娠子宮 2 例化つき血管注入鋳型標 本を作製しえたので，その所見につき追加報告する。

第 1 例：成犬 $15 \mathrm{~kg}$ 体重, 子宮内胎児 7 頭, 子宫の大きさ は長经右 : $33.0 \mathrm{~cm}$, 左 : $31.0 \mathrm{~cm}$, 胎盤部での幅径右 : 6.0 $9.0 \mathrm{~cm}$, 左: $6.0 \sim 10.0 \mathrm{~cm}$. (1)子宮動脈幹の太さ: 右 0.20 $\mathrm{cm}$, 左 $0.16 \mathrm{~cm}$ ，(2)子宮動脈の主要分枝数：在 12 本，左 12 本, 径の平均右 $0.08 \mathrm{~cm}$, 左 $0.07 \mathrm{~cm}$. (3)胎盤構成に開与寸 了分枝数右 $2 \sim 4$ 本, 左 $2 \sim 4$ 本. (4)子宮静脈幹の太さ右 0.36 $\mathrm{cm}$, 左 $0.32 \mathrm{~cm}$. (6)子宮静脈の主要分枝数右 10 本, 左 10 本. (6)各胎瞥上り流出する静服枝の数右 2 4 本, 左 2 4 本.

第 2 例 : 成犬 $26 \mathrm{~kg}$ 体重, 子宮内胎児 6 頚, 子宫の大きさ は長径右 : $64.0 \mathrm{~cm}$, 左 : $31.0 \mathrm{~cm}$, 胎盤部での幅径右 : 9.0 $10.0 \mathrm{~cm}$, 左: $8 \mathrm{~cm}$. (1) 子宮動脈幹の太さ右 $0.37 \mathrm{~cm}$, 左 0.33 $\mathrm{cm}$. (2)子宫動脈の主要分枝数右 14 本, 左 11 本, 径の平均 右 $0.17 \mathrm{~cm}$, 左 $0.15 \mathrm{~cm}$. (3)胎盤搆成江関与する分技数右 3 4 本, 左 2 6 本. (4)子宮静脈幹の太さ右 $0.64 \mathrm{~cm}$, 左 0.63 $\mathrm{cm}$. (5)子宮静脈の主要分枝数右 9 本, 左 8 本. (6)各胎篮より 流出与る静脈技の数右 $1 \sim 3$ 本, 左 3 本. (7)子宫動・静脈主 幹の蛇行性：第 1 例 $(-)$, 第 2 例 (+).

\section{C-4）ラット足睡の恔性刺激による肉芽堙形成の 竍容時期とその形態学的穓察}

$$
\begin{gathered}
\text { 老人病研究所基礎部 杉山誠・堤 倩朗 } \\
\text { 金子 仁 }
\end{gathered}
$$

老化の譏序究明の一罢として，慢性機械的刺譤によるラ。 卜足䀧肉芽腫形成を許容する時期と, その形態学的变化を 観察した．実稌動物には Wistar 系ラット㫿を用いた．太さ $800 \mu$, mesh の大きさ $1 \mathrm{~cm}^{2}$ のケージで飼育することによ り，自重による慢性刺澈を与元足睡に肉芽形成を惹起した。 これを骨格標本，硬軟 X 線による单純撮影，動脈造影とその

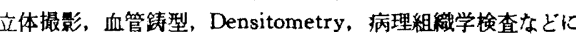
より観察したそその結果，X線像，組織像では，線維性結合 織の增生，血管の新生を伴う非特巽的炎症性肉牙で，病变が すすむと，石灰沈着，骨の破壤打よび反応性の增生をみた。 これらの肉芽の增殖経過を，血管造影の実体顕微鏡下立体観 察，Densitometry でみると，血管は演竞を中心に，後部 骨動脈本幹より肉芽を取り巻くように棱線うたいに発達し，

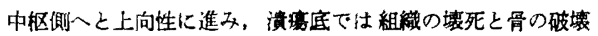
へとつながる.これらの病变をもたらす要因としてはおよ そ14 16 力月以上儿及ぶ反復刺数を要し，この点経時的変 化である、また，加重負担が大きく，体重の重いすのほど高 度である。これ性平衡覚失調などで，片側化体重のかかるも ので如実に現われた．さらに重要なのは，ラットの足の解剖 学的な特徽で, 加重蝩骨および第 5 中足骨中权 $1 / 3$ でも。 そもかかり，しかも該部では，血管の発達が生理的㐳きわめ て悪い，以上の理由で，組織の壊死と反応性増殖をきたすこ とを上述の実駼手段で証明した。

\section{C-5） ヌードマウス胸腺残基の微細櫵造}

\section{第 2 病理 石河图子}

ヌードマウスはnu遗层子によって支配される体毛と胸腺 の形成障赛がある。演者は新生児， 4 週，2 力月， 3 力月の

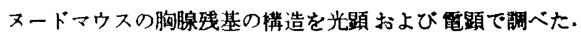
胸腺残基は心房の上方位位置し，肉眼的には二葉からなり， 
大きさは直径 0.5 2 $\mathrm{mm}$ 程度である. 多葉性の脂肪組織や

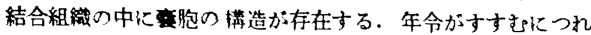
ては大きくなり、コロイド様の物質が賍っているのがみられ る.翼胞を形成する細胞は新生児では microvilli をもち， glycogen に富み，golgi 装置のよく発達した細胞で，細胞閒 には desmosomeが存在する. 4 週令以降では，短い microvilli をつつ扁平な細胞の他に， cilia を持つ細胞や， goblet 棣の粘液細胞，golgi 装置がよく発達した，不定形の分泌顆 粒をもつ細胞などが存在し，各細胞間化は desmosome が存 在する、このような cilia を持つ細胞や粘液細胞は，ある共 胞には多いがある胞胞はむったく存在しないことが多い。 言胞のまかりには末分化な分泌細胞の形態を示す細胞集団や 粘液細胞が存在し、血管も数多い。しかし、リンハ球は注と えビみあたらなかった。

\section{C-6）血管平滑筋湅胞に関する実験病理学的研究}

\section{第 2 病理 間 武雄・回山孝二・石河国子 福士勝成・浅野伍朗 中央電子影微镜室 鉿木克哉}

動脈硬化など血管病変の成立㙨序の解明の目的で組織培鉒 法での血管平滑肪細胞の持つ機能的多様性を検討した。

方法：実験 I ; 胎児ラットと成熟ウサギの大動脈小片を Ham 12 medium +20\% 仔ウシ血清で培斏し，経時的に光影

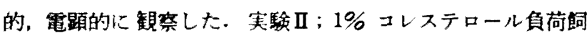
育と無処監ウサギ大動脈小片をミリポフーフィルター上に载 せtest tube 内で回転培養を行い経時的に 1，3，4，5，7，9 日 で光影的, 電㩆的ならびに $3 \mathrm{H}$ proline, $3 \mathrm{H}$ thymidine $の$ 取込みを autoradiography を用いて観察した。

結果 : 単層培養法による胎児ラット大動脈の平滑勋細胞は 培答 1 日後より，いくつかの細胞集団として值線状あるいは 放射線状任配列增殖し，細胞の一部はリボン状で紡鍍型細胞 とともに束状の堌生形態を示す。殿細楼造的に 細胞質内儿は 豊富な golgi 体, 粗面小胞体の発生とともに ribosomes の 線状配列，myofilament の形成を認め，細胞質縁に局在し基 底䐜側に移行している．回坛培篦法ではコレステロール負荷 群は対照群に比し培養 4 日頃より䉼腫下の平滑筋細胞の走行 の乱れと核肥大, 細胞間のムコ多䗷体の増量, 膠原線維の増 生が顕著となる.コレステロール負荷に伴い大動脈内皮内に 增加する泡沫細胞形成化基底部の平滑能細胞の関与が注目 され脇細胞の粗面小胞体の堌生, 滑面小胞体の空胞化, 脂肪 滴の増生と $3 \mathrm{H}$ thymidine, 3H proline の取込みなどはそれ らの平滑笳細胞の堌殖と楾維形成能を裹付けていた。

\section{C-7）癌患者における免疫能の検索}

\section{第二病院内科 奥平邦雄・斎藤正人 小川富夫・岩瀬 滋}

癌患者における免疫能を検索する目的で今回われわれは以 下の検索を行い興味ある成績をえたので報告する．

対象：健常人および良性疾患高令者を対象とし，当病院内 科，外科の入院癌患者について検討した.

$$
\text { (443) }-65-
$$

方法: 1) PHA skin test; PHA-P $100 \mathrm{ug} / \mathrm{ml}$ の $0.1 \mathrm{ml}$ 皮内接棰後 24 時間後その和斑を測定した. 2) PPD skin test； 一般診断用 PPD を用い, PHA skin test と同様汇测定した。 3）本梢リン八球 subpopulation の同定; 矢田らの方法にした がい，E-RFC，EARFC，EAC-RFC を算定した。 4) PHA blast formation test; Conray-Ficoll 法にて末梢リンバ球を 分離後, 72 時間 $37^{\circ} \mathrm{C}$ 培莨, その芽球化を形態的に算出した. 5) FC+-T cell の梌出; 矢田らの方法にしたがい, double rosette formation method $よ り$ b, Sh-E-RFC, CK-EARFC, CK-EA と Sh-Eの double rosette およびいずれの rosette を形成しない null cell の 4 種類を算定した.

結果 : Skin test で恃 PHA の方に癌患者に有意の低下を みた. リンハ球 sabpopulationでは EA RFC で上昇の傾 向をみた. PHA blast formation では癌患者においてはその 低下がいちじるしかった．FC+-T cell は瘦患者では，正常人 に比し著明に增加していた。

\section{C-8Ｖitamin E による抗癌剂副作用抑制に関 する実験病理学的研究}

$$
\begin{aligned}
& \text { 第2 病理 } \text { 近添拓世·佐藤正紀 } \\
& \text { 林 芳孝・福士勝成 } \\
& \text { 第2 生化 平井幸彦・吉野芳夫 }
\end{aligned}
$$

癌化学療法に不可久な各種抗癌绪は, 癌織のみならず正常 組織をも破壊する致命的な副作用を有し，化学療法の大きな 障害となっているので, 細胸分裂必需ビタミンである Vita$\min E(V E)$ により抗癌绪副作用抑制実験を試みた。副作 用が激しく，持続性で，もっとも一般的使用されている $\mathrm{MMC} の \mathrm{LD}_{\mathrm{s0}}$ 量を $\mathrm{dd} / \mathrm{Y}$ 誠熟マウス $(15 \mathrm{mg} / \mathrm{kg})$, Wistar 系成熟ラッ卜 $(3 \mathrm{mg} / \mathrm{kg})$ に皮下注射した. マウスにおける 死亡率は, VE 正常投与群 (VE $1.6 \mathrm{mg} / 100 \mathrm{~g}$ 体重 $/ \mathrm{d}$ ) 755 $\%$ ，VE過剩投与群 (VE $50 \mathrm{mg} / 100 \mathrm{~g}$ 体重/d) で $25 \%$ と, VEによる延命効果が認められた. VE 含有量を異にして離 釈期より 7 カ月間飼育したラットでの MMC 性死因は盲腸を

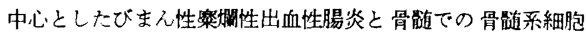
の変数・減数を伴った造血機能低下と脂肪細胞の補空性增殖 であり，他 MMC 性病変として精坚の造精系細胞と肝細胞の 变性を主体とした退行性病变などであり， life cycle の短い

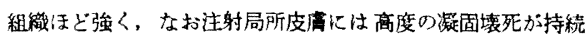
するが,これら病変はすべてVE欠乏群に激しく，反対にVE

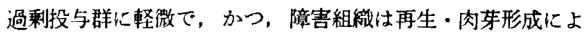
り修復され、VE 含有量の多い群ほと旺盛であり、VEの抗 癌戍副作用抑制に㩆著な有効性を実証しえた。

\section{C-9）痁予防に関する実験病理学的研究（第 3 報）}

$$
\begin{aligned}
\text { 老人病研究所基踨部 } & \text { 金子 仁・杉山 誠 } \\
\text { ワクチン療法研究施設 } & \text { 藤田敬四郎 }
\end{aligned}
$$

バロチン，丸山ワクチン、ビタミン Eの発癌に及ぼす影響 を検討した、第 $1 ， 2$ 報と同様化生後 2 力月 ICR マウスを 30 匹ずつ 5 群に分け, 対照群, 二コチ群 (体重 $10 \mathrm{~g}$ に対し ユベラニコチネート $0.02 \mathrm{~g}$ 食㽠に加), ハロチン群 (パロチ ソ $5 \mathrm{mg}$ を $2 \mathrm{~m} l$ に浴かし, $0.2 \mathrm{~m} l$ ずつ週 2 回注射), 丸山 
$-66-(444)$

群 (丸山ワクチン $\mathrm{A}$ を $0.1 \mathrm{~m} l$ ずつ週 2 回注射)，ビタミン $\mathrm{E}$ 欠群 (離釈直後よりオリエンタルのビタミン $\mathrm{E}$ 欠そ食) とした. 投薬と同時に背部皮虚に市販のコールタールを週 2 回整布し 5 力月で屠般し，皮病病变を病理学的に桧尌した。 途中死もあったがタール勧布後 4 力月半以上生存した例は柾 例比加えた。一般に 4 力月位で発癌するかららてある。

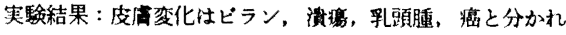
る、癌はすべて扁平上皮癌である，癌の大きさを組織学的化 みて, 大ま加大大, 中, 小と分けた。癌発生事性対照群 28 匹 中 17 例 (61\%), 伿チン群 28 匹中 14 例 $(50 \%)$, = 于群 28 匹中 14 例 (50\%), 丸山群 30 匹中 16 例 (53\%)， ピタミン上群 29 匹中 23 例 $(79 \%)$ である。

結㖮：1）癌発生串は対照群，バチン群、二コチ群，丸山 群の間で著差はない，数の上では対照群にもっとも癌発生が 多く、大きい癌は二コチ群にもっとも少なかった２）全群の 中でビタミン E久乏群にもっとも癌発生が多かった，3）リ ン八球，マストセルの数㤌各群ともに著差はなかった，4)

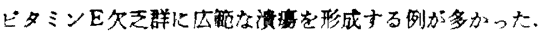

\section{C-10）超音波匙断菨置の分解能向上に関する検时} 一上腹部雚器病変に関して一

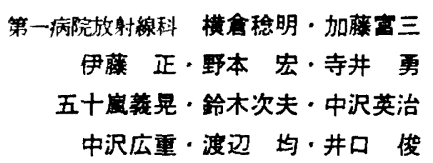

徒来の超音波断層猃断法は解像力の限界および断層像の描 出判定に術者の高度の熟練を必要とすることなどにより，診 断能および客観性に大きな限界を有していた．今回われわれ は集束型探触子および semi log. amp. を入手したので，基

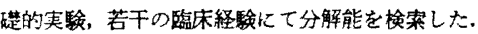

装置および方法：診断装置は ALOKA SSD-60C (Eu3006), SSD-60C (Eu-3006 S. log.), 探触子は ALOKA PZT $2.25 \mathrm{MHz} 10 \phi$, ALOKA UST-2234 2.25 MHz 7.5 R $10 \phi$ を使用し, 画像記録装置 ULR-2 型 (scan converter) に連結し，VTR および NISE NICE FORMAT で録画撮 影した。

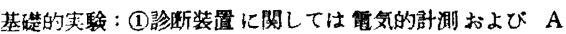
mode 法の視覚的計測を行った、(2)探触子に関しては陰画紙 法による計測を行った。

結果: 信断装置住 S. log. amp. で dynamic rang 約 60 $\mathrm{dB}$, linear amp. で約 $40 \mathrm{~dB}$, grey scaling は $\mathrm{S}$. log. amp. で約 14 階調, linear amp. で約 10 階誈で明らかに S. log. amp. の性能がすぐれていた。探触子は集束型探触 子が源度 $6 \mathrm{~cm}$ 以深で著明に方位分解能がすぐれていた。 Scan converter は残光性画像と比較し, 画像の完成度, 貶録 の多栐性，即時性化すぐれている.

結論 : 上腹部超音波部断化は (S) log. amp. +集束型探触 子+scan converter の組み合わせが有効であると考える. 症 例数はいまだ少ないが旰内脈管の描出，膵描出心すぐれてお り，胆壁の肥原の程度をでをも観察しうる．今後肝胆膵の 腫镑の早期発見に大きな可能性がもたれる.

\section{C-11）EMI-scanner CT 1010 の使用経験}

\begin{tabular}{|c|c|}
\hline \\
\hline \\
\hline \\
\hline \\
\hline 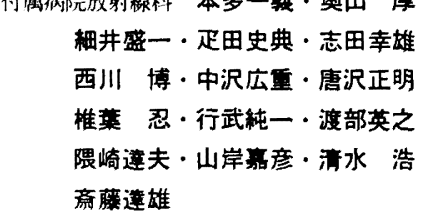 & 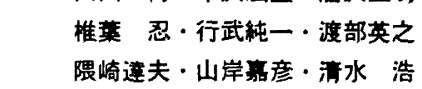 \\
\hline
\end{tabular}

$\mathrm{CT}$ scan 己は促来の X 線写真化よる診断之異なり，細い $\mathrm{X}$ 線ビームを人体の体軸之ほほ值角比多方向から照射し，え られた多数の透過線量分布四をもとにしてコンビューターを 用いて被写体䩤断面における吸收線量の分布図をえるもので ある、その特徽は促来の X 線フィルム写真では到底表現しえ なかった極く微小な X 線吸収差をも表現しうるようになった ことである，例えば，脳実質と脑室，白算と灰白質を識別す ることができる。付原病院では，昭和 52 年 5 月，頭部專用 である EMI scanner CT 1010 が設置され，同年 9 月 9 日ま でに 489 例，580 回の撮像を行ったので報告する.

方法：テント上の検菜には，外眼角と外耳道 (OM-line) に 平行に,テント下ではこれより後方 20 度傾いた線に平行に, 眼㻤の梌索には前方 20 度頃いた線に平行に位膡を決定し，

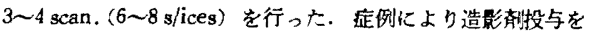
行い，投収差を增強させた。

成績： 489 例中 $62.8 \%$ に異常所見を発見した，そのうち 腫镜性病变 39 例, 血管性病变 83 例, 外伤 16 例であった。 これらはその位置形態を直接的に明膫に認識しうるものであ つた。

結語：CT は検查時間が 1 scan (2 s/ices) 60 80 秒と短か

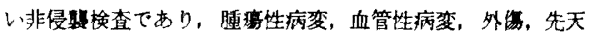
性異常などに対してきわめて有用な手段であると考える。

\section{C-12) Cronkhite-Canada 症候群の 1 例一とく にその病理組耭学的所見一}

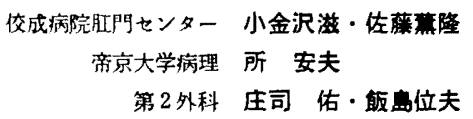

症例: 40 才女

主訴：虫血，下浰，全身倦念感

既往歴として, 昭和 43 年胃溃资で胃切除術をうけている. 昭和 45 年 9 月から 11 月に加け一, 下利, 味賞低下(甘味 とから味), 頭髮の脱毛, 爪の背曲・脱落, 顔面皮度の色案沈 着をおぼえ，さらに下㰾の增悪により他病院より紹介された。

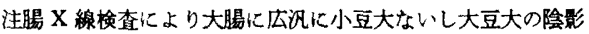
欠損が認められた。保存的治撩により改善かみられないため,

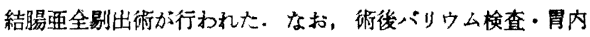
視鏡梌查により胃・小腸にもボリーブが認められ, 術後4 力 月頃より爪甲の㜪縮・眖毛および便通回数の改善が認められ た.

亜全剔された結腸の標本の粘膜面におけるポリーブ全部 69 
コについて病理組維学的に検案が行われた。1）腺の增殖が少 なく，不規則．2）間犋が非常に広く，粘膜固有層が多い，3)

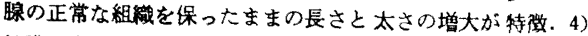
粘膜固有層化は形資細胞，リン八球，組織球，好酸球，好中 球などの小円形細胞の浸潣が認められるが，その組成は特別 儿特徽を有しない，5）粘膜固有愿における小円形細胞の浸润 が多いため，粘膜上皮が剥離されやすい，6）粘膜上皮には， ボリープの形をとらない扁平な增殖が認められる、7)粘膜の 增殖が認められ，これは真のボリーブではない。

\section{C-13）ママゥス障害肝の検討（1）-OAT 短期投 与一}

\section{街生・公衅衛生 佐藤諦吉・若山菜子 吉川泉・柚木 斉}

肝障害時における血清成分の量的質的変動と病理組繶との 関連性の基礎的な知見をえることにより，地城集団における 所疾患の病態把握に役立てることを目的とした。

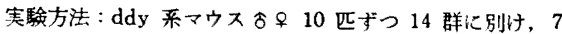
群にはOATーグリセリン溶液を 1 週に1度腋下に接種した。 各群は接理後 $4 \cdot 24 \cdot 48$ 時間・ 1 週間および $2 \cdot 3 \cdot 4$ 回目 の接理後 1 週問で屠殺した，対照群 7 群はグリセりンを接種 し, 同様に処理した. 肝棬能模査は GOT, GPT, Al-P, LDH, T. chol，について行った. 免疫学的検查として成熟マウスの 肝特異抗原以抗血清 (ウサギ)を作製，ま大抗一F抗原血清を Fravi の方法 [Path-Microbiol $31: 257$ (1968)] で作製し,

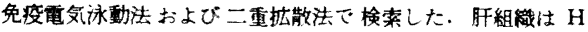
固定で H·E, PAS, V.G にて染色し検镜した。

実駼結果：今回突施した䀒機能挨查におりてては投与期間中 を通して，著明な変化はみられなかった，肝特翼抗原および F一抗原は使用した娭索法では全群傜出されなかった。病理 租織変化は，投与初期〜中期のリン八球を主とするグリンン 氏当の細胞浸濶之結節状の細胞浸潤が特徽的であり，実質細 胞核の大小不同，核および細胞質の浱染なども認められた。 PAS 陽性頖粒は投与全期を通じ，対照群に比べはなはだ多く 認められた。

C-14）ママウス障害肝の検討（2）-CCl、短期投 与一

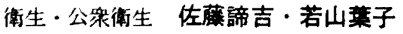

$$
\begin{aligned}
& \text { 吉川泉・柚木 斉 }
\end{aligned}
$$

前報（演䦽（C-13））の OAT 投与実験と同じ目的で，試 蒋を $\mathrm{CCl}$ 、に翂元実駼を行った。

実験方法：ddy 采マウス 6 ㅇ 10 匹ずつ 14 群に別け， 7 群には CCl。ーオリーブ油溶液を 1 週に 1 度経口投与した. 各 群は投与後 $4 \cdot 24 \cdot 48$ 時間・ 1 週間および $2 \cdot 3 \cdot 4$ 回目の 投与後 1 週間で屠殺した. 対照群 7 群はオリーブ油を投与

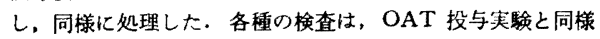
に行った。

実験結果: 肝機能検査では 投与後 $4 \cdot 24$ 時間時の GOT, GPT, LDH の上梨が著明で， Al-P は軽度の上昇を示した。
(445) $-67-$

さらに肝特異抗原, $\mathrm{F}$ 抗原が同時期に血清中に認められた. 病理組䋨变化は肝細胞の著明な簀死が特徽的で，とくにグリ ソン氏鞘を中心とした周辺寡に多く，小葉中心帯は比較的残 存している. 投与第 1 週目にとくに変化が激しく, PAS 陽性 顆粒もこの時期に多くみられた．後期になると壊死細胞の数 も隇り，小葉構造も正常な状態となる。

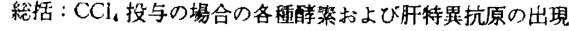
は、肝細胞の著明な壤死飞伴う盰細胞内成分の流血中への放 出が原因と思われる.これに比べ OAT 投与の場合は細胞漫 澗が主で肝機能検査などには変化がみられなかった．今後, 長期にわたる慢性旰疾患のモデル実験を行い，とくに肝硬変， 旰癌への移行時における血消中の各種成分の量的貿的変動を 詳細比梅就する予定である。

C-15) シスチンを含有し，稀有な組成を示した胆 石の 1 例

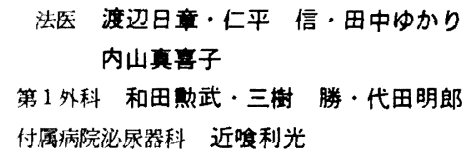

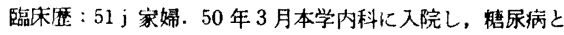
胆石症の診断で， 4 月に第 1 外科比転科，同月 14 日 cholecystektomyを受计た.

胆石: 大・小 3 個よりなり，その 1 つは最大径 $3 \mathrm{~cm}$, 長さ $6 \mathrm{~cm}$, 長梢円形, 表面色調は緑色と褐色の斑状を呈す。割面 の外層はほほ 4 層をなす薄い層状を示し，中心愿注核より放 射状結晶配列を示し，肉眼的には cholesterol (以下Ch. と略 す）結石と診断された。

胆石の主成分の分析結果：1) 外曆の褐色斑状部分. (1) I.R. でCh.+L-cystine が主成分であることが同定された。 (2) X 線回析で，L-cystine 々同定された。 (3)この粉末を, ether, chloroform, MeOH で段階的な抽出を試みたか，まったく 不溶で， $1_{\mathrm{N}}-\mathrm{HCl}$ でのみ可溶性であった（4) 2 種類の溶媒を 用いて，てれぞれ薄層クロマト法で展開し，L-cystine と 一致する Rf 值およびニンヒドリン発色を示した（〕このも のを口紙化付着させでトロブルシッド反応を行い陽性であ

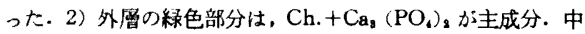
間層の最外層汢, Ch. $+\mathrm{Ca}_{2}\left(\mathrm{PO}_{4}\right)_{\mathrm{s}}$ 十不明成分（かなり多量を 含む）か認められ，他の 2 層と中心層ならびに核は主成分は Ch.であった.

考案ならびに結論：この胆石の表層に Lc-ystine が含ま れていることが確認された．この物質が，いかなる機序によ り胆汁中に排出または分解されて胆石に沈着し，その成分と なったかについてはまったく不明である。

\section{C-16）先天性胆䆓欠如症の 1 例}

$$
\begin{gathered}
\text { 第3 内科 大関正和・古川陽太郎・石田 博 } \\
\text { 前田 宏·永島宏二-黒田 } \\
\text { 小林正文・常岡健二 }
\end{gathered}
$$

先天性胆筫欠如症の 1 例を経験したので報告する. 
$-68-(446)$

患者: 鼡○正 $\mathrm{O}, 24$ 才, 男性.

主訴: 右季肋部痛.

既往歴, 家族歴：特記すべきものなし。

現病歴: 昭和 52 年 5 月 21 日扰よび 6 月 2 日激しい右季 助部痛が出現のため, 某病院に入院. 胆石症の疑いで DIC， ERCP を施行。しかし，胆衰が造影されず。“無胆衰症”の 疑いで当科入精查のため，同年 6 月 20 日転院.

入院時現症：球結膜黄㾝なし。体温 $36^{\circ} 7^{\prime}$. 胸部聴打診上翼 常なし、腹部平坦、㜞で右季肋部に軽度の緊張をみるが圧㴼 なし、肝、脾，腎は触知せず。

検查所見：肝機能娭查でGOT, GPT 值がやや高いほか, 血液, 血沈, 生化学, 電解質, 尿, 猉便検査江異常なし. 胸 腹部 X 線検查、胃十二指腸透視で著变なし.十二指腸液検查 で B 胆汁次如. 腹腔鏡検査で通常胆が観察される篹囲儿胆

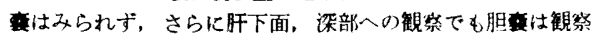
されなかった、また，肝，胆萦のシンチグラム，胆衰の超音

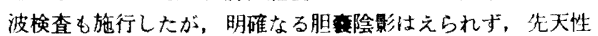
胆需欠如症と診断した。

入院後の释過: 入院後, 右季肋部痛はまったく消失. 試験 的に利胆刋の投与を行ったところ, 早朝心窝部痛が出現.こ の痛みは鎮痛㔀の投与により安易に消失するものであった。 利胆绪の中止によりこの痛みもなくなり，昭和 52 年 7 月 18 日退院.

\section{C-17）集検発見胃察の分析一第 3 報，第 1 回目の 予後調查結果について一 東京中央放射線診缶所 村田雄一・長谷川正浩}

われわれは昭和 44 年 4 月〜 51 年 3 月までの 7 年間に, 総計延へ 439,322 件 (男 332,382 件, 女 106,940 件) の胃 集検および追跡検診を行ったが，手術で確認されたもののう ち, 肉腫は 3 例, 胃湾は 335 例（そのうち早期は 135 例）で あった. 今回, 胃癌症例のうち, 住所判明した 258 例につき, 術後の予後調查（第 1 回目）を行い，併せてわれわれの発見 胃癌全体の姿を分析して，予後結果との対比を武みた。

回収された調查票は 152 通で回收革は $58.9 \%$ であった。 この 152 例中癌死 18 名, 事故死 1 名, 他病死 2 名, 病议通 院中 2 名, 現在健康者は126 名であり，その他化毎年の集検 で現在健康であることが判明したもの18 名が認められたの で, 現在健康者注, 合計 144 名であった。

現在健康者 144 名中 5 年以上健在者は，5年 21 名，6年 12 名, 7 年 2 名の計 35 名であり，4 年以下の健康者は, 109 名であった. 5 年以上健康者 35 名中, 深達度 $\mathrm{m}$ は, 15 例, $\mathrm{Sm}$ は 5 例, $\mathrm{Pm}$ は 5 例, SS 10 例で, 深達度 $\mathrm{S}$ 以上の むのは認められなかった。 また，癌死した 18 例深達度 $\mathrm{m}$ はなく, $\mathrm{Sm}$ は 1 例, $\mathrm{Pm}$ は 0 例, SS 2 例, $\mathrm{S}$ は 4 例, $\mathrm{S}_{2}$ は 3 例, $\mathrm{S}_{\mathbf{8}}$ は 2 例, 切除不能例は 6 例であった。

5 年以上健康者中, 深達度 SS 以上の 10 例と, 癌死した 18 例中の早期 $\mathrm{Sm}$ の 1 例とを選び，その病理，肉眼分類， 部位, 病紧の広已，年令，性別などにつき検討し，症例展示 を行った，また，発見胃癌全体の姿を整理発表した。

\section{C-18）羘䑏の外科的治幥経倹}

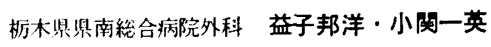

$$
\begin{aligned}
& \text { 川村一彦 }
\end{aligned}
$$

当院で昭和 51 年 2 月より 52 年 8 月までの 1 年 7 力月間 に手術した膡疾患は 13 例で, 手術々式別には膡全摘 2 例, 膵頭十二指腸切除 (Child 法) 2 例, 膵体 - 尾部切除 1 例, 膵

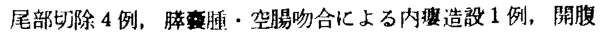
ドレナージ 3 例である. 原因疾患別には胃癌 5 例, 搼癌 2 例,

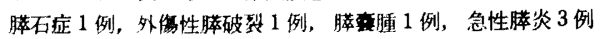
で,このうち急性膆炎の 3 例は急性腹症の猃断で開腹したも のでいずれもドレナージのみ施行した．膵全摘施行の 2 例の うち1例は閉塞性黄㾝をきたした勝压沉癌であり，術後 7 力 月間生存したが癌死した. 他の 1 例は 33 才のび慢性膆石症

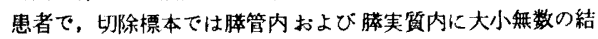
石を認めた。膵全摘後 1 年 8 力月経過した現在，レタード・ レオ・インシュリン 16 単位早朝 1 回笳注にて血蛒值も良く コントロールされ元気化社会復衡している. 胃癌の際の膵合 併切除 5 例のうち 4 例は膵尾部切除であるが，1例は腾頭部 に癌の浸濶が及んでいたため，墙頭十二指腸切除を施行した

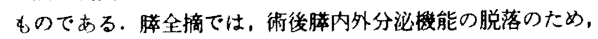
榙質代辢障害, 消化吸収障害が必発であるから手術適応に十 分留意すべきことはいうまでもないか，やむををず膡全摘化 踏み切る际には術後管理を臀重儿行わなければならない。 た，胃癌の際の膵合併切除儿は筫否两論があるが，われれれ は根治性を高める目的で，膵浸潤の認められる胃癌には積極 的に膡合併切除を施行している.

C-19）轱移性腫痽の $\mathrm{X}$ 線学的検討一第 1 報, 肺 腺痦の肺転移像について一

$$
\begin{aligned}
& \text { 付属病院放射線科志田幸雄・斎藤達雄 } \\
& \text { 清水 浩 - 山岸嘉彦・隈崎達夫 } \\
& \text { 渡部英之・行武純一・椎葉 忍 } \\
& \text { 唐沢正明·本多一童・西川博 } \\
& \text { 疋田史典・細井盛一・奥山 厚 } \\
& \text { 東京中央放射線部察所 長谷川正浩 }
\end{aligned}
$$

最近， 3 年間（昭和 49 年 4 月〜 52 年 5 月）に観察しえた 肺腺癌の肺転移 X 線像, 67 症例について検討を行ったので 報告する. (1)性别は男性 41 人，女性 26 人であり，50才代 をビークにして，34〜80才までに広く分布していた. (2)原発 部位㤹下葉にもっとも多く, 右上葉, 左下葉, 右中葉, 左 上葉の順であった。また，胸水眝溜のため，17 例は原発部位 不明であった. (3)肺腺癌轱移の特徽像と思われる两側びまん 性散布性陰影の早期から経過観察しえた症例では, いわらる 肺紋理增強像〜点状陰影〜微細粒状影〜粒状影〜融合像の释 過を呈した (点状 $1.5 \mathrm{~mm}$ 以下, 微細粒状 $1.5 \sim 3.0 \mathrm{~mm}$, 粒状 $3.0 \mathrm{~mm}$ 以上). 67 症例のびをん性散布像の中で, 6 例 は innumerableよりむ numerous の像を呈し, 経気管支散 布も一笖疑われる。 (4)肋膜炎の合併は 41 例 (61\%) で，原 発坚と同側のものが 40 例であった。 (5)肺癌の分化度による 
$\mathrm{X}$ 線像の差異については，今回検討しえた症例が少数例のた め, 確定的なことはいえないが, 差巽はほとんどなかった。 (6) X 線像の経過仗よっては, 肺胞上皮癌との䟝はむずかし い. (7)肺腺癌 (ことに末梢発生のもの)のX線像の祮影に際 しては、びまん性散布の早期発見を心掛けて治療上の指針と することが望ましい。

\section{C-20）進行乳癌に対する両㑡卵宩副䁌摘除術}

$$
\begin{aligned}
& \text { 杤水県県南絰合病院外科 小関一英・益子邦洋 } \\
& \text { 川村一彦 }
\end{aligned}
$$

乳癌に対する内分泌療法は, 根治手術不能の進行乳瘦拉よ び再発転移例に対する症状改善の目的と, 根治的乳房切断術 (以下乳切と略) 後の再発防止の目的で行われる.われわれは 昭和 51 年 5 月より, 本年 2 月までに 4 例の進行乳癌および 1 例の再発乳癌患者に，ホルモン療法として「雨测卵巣副㹂 剔除術」(以下木療と略) を施行し，5例中 3 例に症状改善な いし延命効果，および再発子防効果を認めた。

症例 1 (47才): 㲎切後, 木㞠を行い, 術後一過性にステ ロイド投与による皮虎㱏状出現をみたが，14 力月释過後も再 発は認められない. 症例 2 (36才) : 乳切後, 局所再発のた, め木庵ならびに䀒転移のため, 䀒左葉切除を施行した。肺転 移もあったが木痖後 1 年 7 力月経過するが症状改善効果を認 める. 症例 $3(47$ 才): 乳切後, 木㞠と同時化肝移のため 肝右葉部分切除を行った.しかし、術後11 日目にステロイ

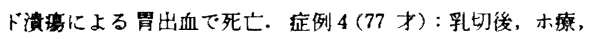
術後 23 日目儿副腎不全症群比て死亡. 症例 $5(71$ 才) : 肺転移あるため, 木珎施行. 13 力月経過するが胸部所見の増 悪は認められない。

本手術施行においては，術前より副腎皮質ホルモンの補充 㮦法が大きな問題である．術中より患者の管理には十分注意 し, 電解質・尿量・血吽・血压な゙，副置クリーゼの発生を 䂆方しなくてはならない。

\section{C-21）乳痘の早期診断に有用な最近の諸検査法}

$$
\begin{aligned}
& \text { 第一病院放射線科五十崖義晃・加藤富三 } \\
& \text { 伊藤 正・横合稔明 · 渡辺均 } \\
& \text { 寺井勇・鈴木次夫・中沢広重 } \\
& \text { 中沢英治・并口俊・野本 宏 }
\end{aligned}
$$

近年, 本邦における乳癌の発生頻度は增加の頋向にあり, しかも社会的に注目を集めている。したがって“早期診断 $\rightarrow$

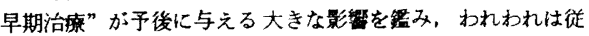
来の諸検査に加え最近の目ざましい技術革新による 2 3 の 新技術（検査法）の導入を逐次陚み，有用性を認めたので諸 検查法の特徵を生かした検查顆位の設定とともに報告する。

䛦断手順：(1)問診，(2)視診、(3)触診、(4)サーモグラフィ (contact th., tele th.), (5)ソノグラフィ, (6) X線学的乳房検 查法 (simple mammography, contrast mammo, ' contrast media, air, xeroradiography, angiomammo, lymphography, (7) RI diagnosis, (8) biological diagnosis, (9)病理学 的診断 (塗沫法, 生検).

要約：(1サーモ，エューは侵憵を加えることなく被曝する

$$
\text { (447) }-69-
$$

ことなく反復検査が可能である.とくに tele th. は釈房のみ ならず胸部全域を描出しうるため病変の描出化適している. (2)エコーは linear amp. 使用の感度断層法や log. amp. 導 入により高解像力の画像をえることが可能となった（3諸検

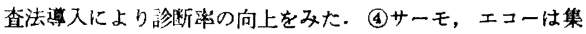
検比利用しうるもので早期発見に有用. (5) contact th. は当 科が本邦最初の使用である.

\section{C-22）骨転移果を主訴とした早期胃癌の 1 症例}

$$
\begin{aligned}
\text { 病理 } & \text { 中川 仁・山中宣昭 } \\
& \text { 山田展敬·森山昌樹 } \\
& \text { 福士勝成 } \\
\text { 整形外科 } & \text { 比企健男 } \\
\text { 老人病研究所基礎部 } & \text { 金子 仁 }
\end{aligned}
$$

癌の骨転移は一般に原発坚としての内贜癌が進行した時期 に起こるむのであるか，まれに骨転移巣がまず発見されたの ら、はじめて原発䉾化注目されることがある。症例は 65 才 男子、昭和 50 年 9 月上旬誘因なく右局から上腕化けて自 発痛が始まり，近医比て右同関節周囲炎との診断で投藻，注 射などの治療を受计たが軽仭せず同年 12 月下旬某病院整形 外科を訪九，上腕骨骨腫琭を指摘され本院を紹介され入院と なった，入院後胃透視にて病変を指摘されたが，全身状態悪

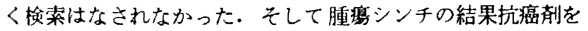
投与したが発熱などのため中止せざるをえなかった，てして 意識障害と高 $\mathrm{Na}$ 血症が現加九, 翌年 2 月 24 日心筋硬塞汇 て死亡した. 剖検の結果胃に Ic 型早期胃癌, 右上腕骨轱移, 脑転移, 顕微鏡的肺轱移と判明した。従来から消化器癌では 骨転移の頻度は一般に低いといわれ，とくに骨転移を主訴と した潜伏胃癌は一層少ないとされている，骨転移癌をその原 発策別化咷めてみると乳癌, 肺癌, 胃癌および子宮癌が主な ものであるが，骨転移染からみると唾液腺癌，腎癌および前 立腺癌が 45 30\% の高晏を示し，ついで肺癌，乳癌の $10 \%$ 前後となる，癌患者の一番多い胃癌では剖検時も含めて $2 \%$ と低い. 原発巣が無症状に経過する場合, 原発畄の早期発見 が漣れる危険性があることを示唆した症例を経験したので報 告した.

\section{C-23）男子勫癌の 1 症例について}

$$
\begin{aligned}
\text { 埼玉県立がんセンター病理 } & \text { 土屋真一・三友善夫 } \\
\text { 第 } 2 \text { 病理 } & \text { 福士勝成 } \\
\text { 第 } 1 \text { 外科 } & \text { 代田明郎 }
\end{aligned}
$$

男性乳癌は，一般化まれな疾患であり，その発生頻度は 1889 年 Williamsが 全乳癌症例中的 $0.9 \%$ と発表して以来, 幾多の報告があるが平均 $1 \%$ 前後とされている．われわれも この男性咷䄆症例を経験し，電顥的に検索する機会をえたの で報告する。症例は 71 才男子, 1975 年 11 月, 右乳頭部の 小指大の腫諨から始をり，その後徐々に增大したため, 翌年 7 月右乳癌の診断のもとに根治的釈房切断術を受けた。なお， 診断時の病期分類は $T_{2} N_{1} M_{0}$ であった. 切除標本は大きさ 21 $\times 20 \mathrm{~mm}$ ，割面仕黄褐色で硬く、組織学的には硬癌であり， 
(448)

固有乳腺絓織と周囲脂肪組禨に存在する腫瘁は中心が硝子化 し，周辺の線維性間質中心は癌細胞がビマン性化浸潤，また 乳腺外脂肪組織中へも索状化認められた。腋密リンバ節には 転移陰性であった，電顥的観察では，Tocker がヒト乳腺の 上皮細胞を胞体の明調，暗調により 4 租化分類したが，同様 にわれわれの男性乳癌細胞も，明調，暗調の細胞を見出した。 癌細胞の配列俚敷石状整築をなし，デスモゾームで接し，一 部 interdigitation 满造を持つ. 閒質へは筋上皮細胞を介する 部分と，直接，基底膜比接する像をみ大，細胞質内には異常 に浸潤し，かっ巨大化した糸精体がす，小胞体の数は減少 する反面，多数の遊離りボソームが目立った。核は，形状の 不正，核貿分布の異常，核小体の增大，僁核封入体がみられ た. 男性乳癌の霓顥的検索は本邦第1例であるが，女性乳癌 の電顥像と大差がないことを認めた。

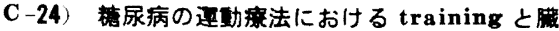 器組織内の代鼠位相の变化（第 10 報）

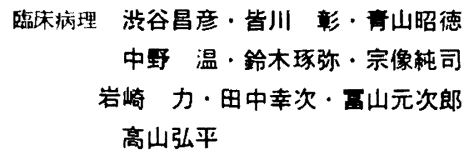

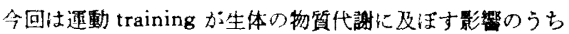

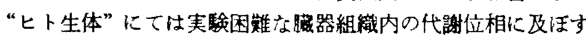

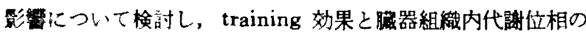
变化との関連を追求した．ことに運動 training を受けた筋肉 組䅧と training を受けなかったそれといかなる相違があるか を S.D. ラットを用いて研究し，組緎内の脂質に及活す training 勃果に関し興味ある結果をえたので報告する. 方法：前 回報告に同じ. 若令 S.D. ラット 60 匹を用いて，一定条作を 通動 training 4 週間にわたり行い，その後 3 日間の休息位 を取らせた群を T群, training 㨁後保解剖し大群を $\mathrm{T}+\mathrm{E}$ 群とし， training を行わなかった正常対照 N 群と比較した。 今回は “上ト”血济脂筫中，変化のいちじるしかった中性脂 肪について S.D. ラットの血清および下肢赤色骨格筋の結果 を報告する。

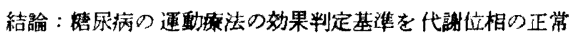
化に求めて, 運動 training の施行前後の推移を锤䋈すると,

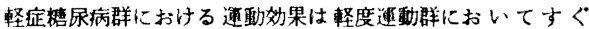
れ，高度運動群は必ずしも良い勃果を示さなかった，その原 因を明らか化するために骨格筋肉内の脂質の測定を行い, training 効果，運動強度との関連を明らかにした。下肢骨格 筋肉中性脂肪量と運動 training との関係を観繁すると対照群 において中性脂肪の堿少はもっともいちじるしく，軽度運 動 training 群では中性脂肪の减少性もっとも軽微で, 高度 training 群の值はその中間にあった。

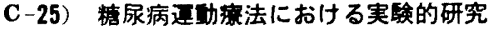 -Streptozotocin 裙尿ラットの血清・踝 器の代璟位相に及ほす荤動の影䇺一

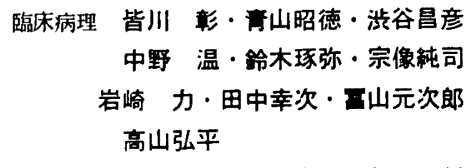 \\ 付庽病院中央㭇查室新宅孝征・㚼哲}

今回，われわれは正常ならびに STZ 精尿ラットを用い燃 尿病時の通動比打ける代謝に打いててミ/酸のはたす役㓶を

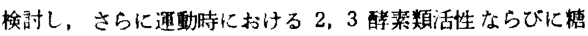
筫，脂質とフミ/酸との関係を明らかにすることに努めた。

1) 中性脂肪 ( $T G$ ) : 軽度 training ( $T$ ) により正常ラッ 卜血中 TG は低下し，高度 Tでは增加傾向を示した. STZ

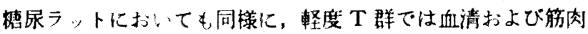
内 TG のいちしるしい低下を認めた，2)酳素類活性：か かる変化の由来を明らかにするために血中、眤器組織中の

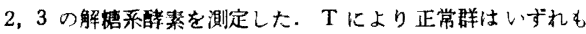
醉素活性增加。榙尿群では低下傾向を認めて両群化著明な差 を認めた。 3) 了ミノ酸 (AA)：Tにより総了ミノ酸,こと に㬝原性 AA は娍少, ケト原性 AA は上昇した。

ラットに training を抗こなえば血清，肝，解に打いて総了 ミノ酸はいちじるしい低下を示したが，ケト原性フミノ酸は 増加傾向を示した．以上のように運動 training 施行前後の丁

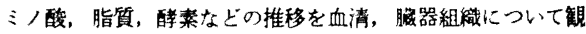
察し, training が代謝位相の変化に重大な影筝をもつことを 明らかにしたが、これらの変化は組織細胞の変調，すなわち

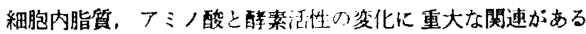
ことが示唆された。

\section{C-26）本学における体外循環法の変缱と現況}

$$
\begin{aligned}
& \text { 付属病院胸部外科耕原俊彦 -中條能正 } \\
& \text { 二宮淳一・平田 滋・浅野哲雄 } \\
& \text { 小坂真一・落 雅美・若林武婎 } \\
& \text { 山手昇・压司佑 }
\end{aligned}
$$

昭和 40 年以来本学で施行された体外循渨下開心術症例 378 例について検討した。過去 13 年間を使用人工肺および 希釈率の変化から 4 期に分類した. 各期化使用された人工肺 名と，各期各年每の充填血液量および希釈革の推移は次のご とくである. 気泡型肺の出現により充填血液量は激减した. 術後出血量比いては，3期，4期は，前期の半分の出血量に て術後を経過している. 次に過去 13 年間における開心術後死 亡店例につき検討を加之た. 死亡例のうち，体外循環と関保を 有する死亡症例の年度每および各時期毎の開心術症例数に対

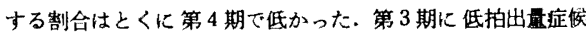
群と思われる症例が多かった。また，死亡例と潅流時間につ いて検誈した。潅流時間が 1 時間を越すと，死亡例数のしめ ろ割合が明らか化增加した，大動服遮断時間と死し例との関 
係は，㵲流時間と死亡例との関保よりさらに明暸で，遮断时 間が 25 分を越えると有意に死亡例数のしめる割合いが增大 した. 体外䛻埥時間と出血量との間には，明膫な相関関倸を みい出しえなかった，カテコールフミンの使用は，潅流時間 と密接な関係があった。体外偱檍離脱時および術後急性期に おけるカテコールフミンの年度别使用率は渐減した。

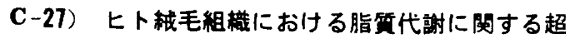 微櫵造的研究}

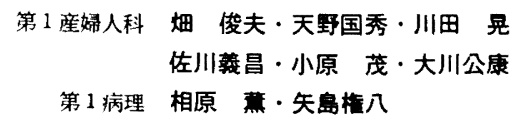

ヒト胎盤絨毛組繊の syncytium 細胞は蛋白性ホルモンと ステロイドホルモン $(\mathrm{SH})$ を同時に産生，分泌し，他の内分 泌眿に類をみない分泌熊度を示しているか，その詳細につい ては明らかでない，演者らは蛋白性ホルモン分泌悌式につい て,すでに免没電㩆的に梌索し報告したが，今回は別の角度 から SH 産生機序解明の目的で超微形態学的愉索を行った。

方法：奼娠初期摘出子宫を用い，䋐毛組織 (CV) と胎児 母体接合部 (FMJZ) に別け，一般二重染色と PAM 染色の ほか，Dermer の橉脂質染色，各種組織化学的方法を合せ行 い検索した。

結果 : CV より FMJZの syncytium 細胞が lipid 顆粒を 多量に含有する.すべての syncytium 細胞の mitochondria の cristae はその lipid 含有量化平行して小胞状化傾向を示 すことは副紧におけると同样である。しかし，特徽的なこと は，侻来他に報告をみない. Mitochondria に似た棰造を示す paradoxal vesiclar structure (PVS) が, その lipid 顆䊉

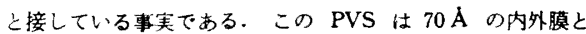
$50 \AA$ の間隚を有し, $130 \sim 370 \mathrm{~A}$ の fenestrationを持つ限界 膜梅造が内外化あり，その間に vesicle, cisterna が存在し て, 全体としてドーナツ状を呈し, Acid P-ase, Al., Pase, ATP-ase 活性を有し，その中心に lipid 顆粒を入れている. さらに PVS 内に lipid と同様の density を有する物質加 存在していることから, syncytium 䋥胞においては, ACTH 投与時の副紧と異なり， lipid 産生能力がきわめて元進した時 にPVS が出現し，lipid 産生の一端を担っているものと考 えられ興味哚い。

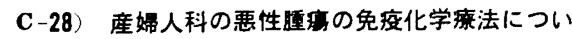
$\tau$

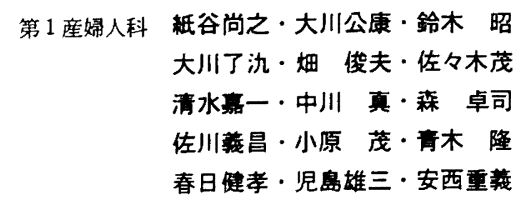

人工酸性多榙体（TGDS）は静注により流血中りン八球を 增加させ、遅延型免疫反応を六進せしめる。われわれは子宮

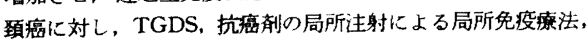

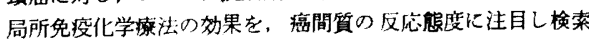

(449) $-71-$

した.

材料および方法: 子宮頚癌手術症例 149 例を対策に遅延型 皮席反応(DNCB テスト、ツベルクリン反応)を参考として。

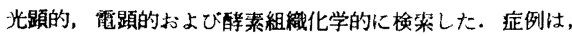
TGDS，抗癌郕の投与法により3群に分類した。

1) 対照群：41 例, 術前無処置. 2) 局所免疫燎法群; 46 例, TGDS $10 \mathrm{mg}+$ gelatin $20 \mathrm{mg}$ 術前隔日局注. 3) 局所 免投化学凄法群；62 例，TGDS $10 \mathrm{mg}+$ gelatin $20 \mathrm{mg}$ 術前 $1 / \mathrm{W}$ 局注 TGDS $10 \mathrm{mg}+$ mitomycin $2 \mathrm{mg}$ (または esquinon $0.5 \mathrm{mg}$ ) 術前 $2 / \mathrm{W}$ 局注.

結果および結稐：1）局所免疫化学療法は癌の間質反応を 対照群に比し有意の差で增強せしめ, 獀実筫の強い退行性変 性を聕起せしめる．2）局所免疫化学療法により癌間斦に著 明化增加与る浸濶細胞は, リン八球, 組絠球系細胞で, acid phosphatase, $\beta$-glucuronidase 活性陽性の細胞が多く、さら に、それらの症例では, 血管采での alkaline phosphatase, adenosiul triphosphatase 活性のて進がられる.3）遅诞 型皮庙反纫陽性例の間質反応は，除性例飞比し有意の差をも , 七強以

\section{C-29）癌患者のリンパ系予備能について}

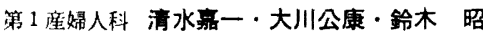

$$
\begin{aligned}
& \text { 㚼 俊夫・佐林茂·中川 真 }
\end{aligned}
$$

今回, 担癌生体の細胞性免疫能の現能力と子備能力を測定 し，予後判定の資料とすることを目的に，(A) 胸腺依存リン八 系予備機能テス卜(胸腺化存領域よりリン八球を動員させる TGDS を用いて), (B) 末梢血 T-cell 数の測定 (細胞電気泳 動法を用いて), (0) 胸腺依存リンハ系予備機能テストにおい て動員された T-cell 数の測定 (同)，(1) 道延型皮店応の 4 法を行った。

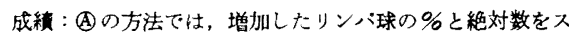
コフで現してみると, 子宫䅡癌 80 例において, T $1 \mathrm{~S}: 19.1$ \pm 7.3 , Т $1: 16.2 \pm 7.2$, T $2: 11.6 \pm 5.0$, T $3: 10.9 \pm 7.3$, T $4: 11.1 \pm 4.3$, 再発群 $10.6 \pm 6.0$ と病期の漫透とともに子 備能の低下が明らかとなり，また退院時スコフが 20 点以上 を示したT1S 2 例, T 16 例, T 25 例, 再発群 1 例, 卵 巣癌 1 例, 体癌 1 例, 外陰癌 1 例, 綸毛上皮腫 1 例の 18 例 は, 外陰癌の 1 例, 䋐毛上皮腫の 1 例を除いて全貝予後良好 であった. 逆に 10 点以下で退院した T IS 1 例, T 17 例, T 210 例, T 33 例, T 47 例, 再発群 7 例, 卵菓癌? 例, 体癌, 外陰癌, 䋐毛上皮腫 5 例の 47 例は, 24 例が再 発または死亡の転㛿を取り，この胸腺依存りンバ系予備機能 テストは，予後判定の資料として十分利用しえることが明ら かとなった.なお，(B)O(D) 3 法に関しても満足のいく結果 がえられた 